\title{
Late Quaternary sedimentary record and Holocene channel avulsions of the Jamuna and Old Brahmaputra River valleys in the upper Bengal delta plain
}

\author{
Jennifer L. Pickering a,*, Steven L. Goodbred a , Meredith D. Reitz ${ }^{\mathrm{c}}$, Thomas R. Hartzog a , \\ Dhiman R. Mondal ${ }^{\text {b }}$, Md. Saddam Hossain ${ }^{\text {b }}$ \\ a Department of Earth and Environmental Science, Vanderbilt University, Nashville, TN 37240, USA \\ b Department of Geology, University of Dhaka, Dhaka 1000, Bangladesh \\ c Lamont-Doherty Earth Observatory, Columbia University, Palisades, NY 10964, USA
}

\section{A R T I C L E I N F O}

\section{Article history:}

Received 1 June 2013

Received in revised form 13 September 2013

Accepted 20 September 2013

Available online $\mathrm{xxxx}$

\section{Keywords:}

Quaternary

Paleovalleys

Avulsion stratigraphy

Valley geometry

Brahmaputra delta

\begin{abstract}
A B S T R A C T
The first Holocene stratigraphic record of river-channel occupation and switching between the BrahmaputraJamuna and Old Brahmaputra paleovalleys is presented here. Motivated by the Brahmaputra River's historic avulsion from the Old Brahmaputra channel to its present-day Jamuna course, we have obtained sediment and radiocarbon samples from 41 boreholes along a $120 \mathrm{~km}$ transect crossing these two braided-river valleys. The stratigraphy along this transect reveals sand-dominated Holocene channel systems, each bound by remnant, mud-capped Pleistocene stratigraphy. Using sediment lithology and bulk strontium concentration as a provenance indicator, we define the geometry and channel-occupation history of each paleovalley. The western Brahmaputra-Jamuna valley is broad and somewhat deeper compared with the Old Brahmaputra valley, the latter actually comprising a composite of two narrower sub-valleys bifurcated by an antecedent topographic remnant. The gently sloped valley margins (slope: 0.002 to 0.007$)$ and high width-to-thickness ratio (W/T: 1000) of the Brahmaputra-Jamuna valley suggest that it was filled primarily through lateral channel migration and the reworking of braidbelt and overbank deposits. Conversely, the two Old Brahmaputra sub-valleys have comparatively steeper valley margins (slope: 0.007 to 0.022) and lower width-to-thickness ratios (W/T: $\sim 125$ and $\sim 250$ ), indicating that these were filled primarily through vertical aggradation of channel sands. We attribute this disparity in valley geometry and fill processes to the different occupation histories for each valley. In this case, the much larger Brahmaputra-Jamuna valley represents the principal, if not singular, river course during the last lowstand of sea-level, with a prominent gravel lag underlying the valley. In contrast the smaller Old Brahmaputra valleys do not appear to have been present, or at least well developed, at the last lowstand. Rather these courses were first occupied during the early Holocene transgression, and we infer that the river had been previously excluded from this region by the relatively higher elevation between the Madhupur Terrace and the Shillong Massif. We also demonstrate that the Brahmaputra River experienced 3-4 major avulsions during the Holocene, with considerably longer occupation times within the principal Brahmaputra-Jamuna valley. Together these observations indicate that occupation history and antecedent topography have been important controls on river course mobility and avulsion behavior.
\end{abstract}

(c) 2013 Elsevier B.V. All rights reserved.

\section{Introduction}

The Bengal basin is a continually evolving depositional environment comprising unconsolidated muds and sands that have been transported and deposited by fluvial processes, principally from the Ganges and Brahmaputra rivers. As a function of active Himalayan uplift, South Asia's intense monsoon climate, and the resulting susceptibility to seasonal flooding in the delta, these rivers are sediment laden and highly mobile through lateral migration and avulsion. The Brahmaputra-Jamuna River channel, for example, has an estimated

* Corresponding author at: Vanderbilt University, PMB 351805, 2301 Vanderbilt Place, Nashville, TN 37235, USA. Tel.: + 16155000264.

E-mail address: jennifer.l.pickering@vanderbilt.edu (J.L. Pickering). average sediment load of $590 \mathrm{Mt} / \mathrm{yr}$ (Delft Hydraulics and Danish Hydraulic Institute, 1996) and currently migrates laterally at rates $>100 \mathrm{~m} / \mathrm{yr}$ (EGIS, 1997). Such river-channel behavior can result in a complex alluvial stratigraphy that lacks lateral continuity. Borehole stratigraphy, therefore, may be difficult to decipher due to rapid reworking relative to the rate of burial of these sediments.

In the Bengal basin, channel evolution can occur over a single season and major rivers are known to avulse relatively frequently (e.g., Morgan and McIntire, 1959; Coleman, 1969; Umitsu, 1987; Bristow, 1999; Sarker et al., 2003), yet current understanding of Holocene delta formation is based on relatively few, widely spaced (50-200 km) boreholes (e.g., Goodbred and Kuehl, 2000; Goodbred et al., 2003; Sarkar et al., 2009). To properly understand the history and behavior of this system, densely sampled core transects were strategically positioned to capture 
the full extent of the Holocene river valleys and underlying stratigraphy. This effort is part of a 5-year, collaborative project designed to understand fluvio-deltaic processes under the influence of active tectonics; results herein are from the first transect of closely spaced boreholes drilled across the Bengal basin (Fig. 1).

The placement of this core transect was intended to capture the complete Holocene stratigraphic record of the Brahmaputra River and its valley systems in the upper Bengal delta. A major river avulsion, detailed in Section 1.3, occurred in the late eighteenth to early nineteenth century as the Brahmaputra River diverted discharge from its Old Brahmaputra course east of the Madhupur Terrace into the present Brahmaputra-Jamuna River course west of the Madhupur Terrace (Fergusson, 1863; Oldham, 1899) (Fig. 1). Within Bangladesh, the current course is called the Jamuna River (referred to as the BrahmaputraJamuna River in this paper; "Brahmaputra" is used when referring to the river in general, without regard to its channel position), and the channel occupied prior to $\sim 1800 \mathrm{CE}$ is called the Old Brahmaputra River. Borehole studies (Umitsu, 1987; Goodbred and Kuehl, 2000) have suggested that the Brahmaputra River has avulsed between these courses several times during the Holocene, but observational data pertaining to the history of these recurring avulsions are lacking.

In this paper we present the alluvial stratigraphy (up to $100 \mathrm{~m}$ depth) that overlies the latest Pleistocene sea-level lowstand (LPSL) surface in the upper delta plain. The LPSL surface reflects maximum valley incision by the latest Pleistocene paleo-Brahmaputra and the corresponding highlands that were exposed as base level lowered in response to the global advance of glaciers during the Last Glacial Maximum (LGM). This surface is coincident with but not limited to the "laterite" of Goodbred and Kuehl (2000), the fine-grained Last Glacial Maximum paleosol (LGMP) of McArthur et al. (2008), and both the paleo-channels and paleo-interfluves of Hoque et al. (2012). We propose the collective term "LPSL surface", which acknowledges the time-transgressive nature of these deposits, to incorporate each of these surfaces.

After identifying the LPSL surface and placing it in stratigraphic context, we compare the morphology and the width-to-thickness (W/T)

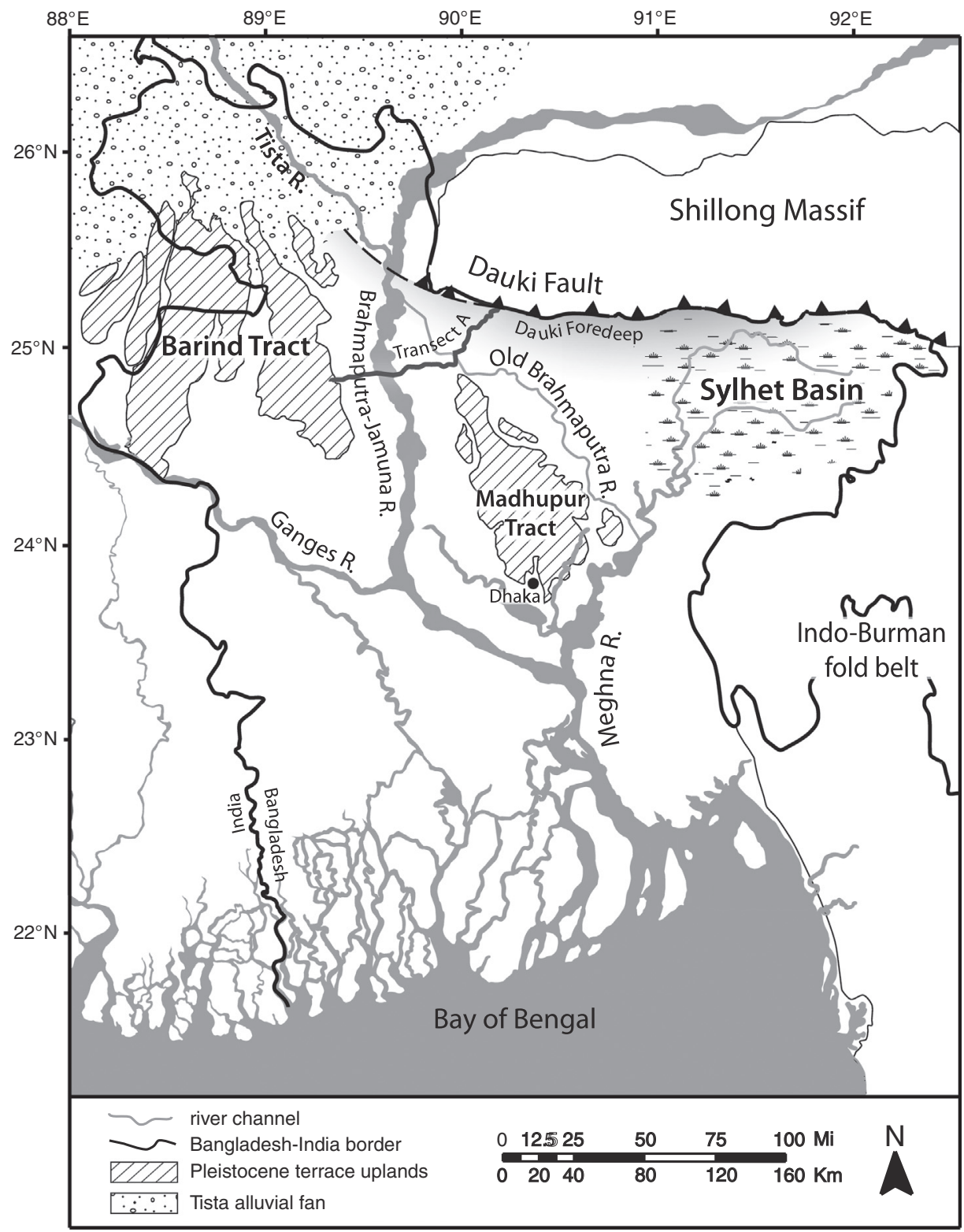

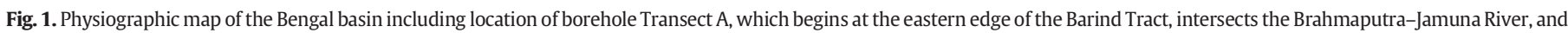
terminates at the Dauki Fault north of the Madhupur Tract. 
aspect ratios of the different Brahmaputra paleo-valleys to infer dominant processes of formation and infilling, e.g., vertical aggradationincision cycles or lateral migration. We also use the valley stratigraphy to identify channel fill deposits separated by preserved overbank deposits as an indication of the number of channel occupations at a particular location. Finally, from these results we estimate first-order avulsion frequencies and channel-occupation timescales for the two major courses of the Brahmaputra River.

\subsection{Contribution to geomorphology}

Theoretical and experimental approaches (e.g., Schumm et al., 1987; Whipple et al., 1998; Cazanacli et al., 2002; Bryant et al., 1995; Hoyal and Sheets, 2009) aimed at understanding channel avulsion behavior benefit directly from the addition of primary information on the manner and rate of channel switching in natural deltas. The occupation timescale estimates we present here will inform current research in theoretical geomorphology, just as our conclusions regarding the tendency of channels to avulse into previously occupied paths corroborate the idea that channels tend to reoccupy former paths (e.g., Mohrig et al., 2000; Jain and Sinha, 2003; Aslan et al., 2005; Reitz et al., 2010). Several explanations for this re-occupation behavior have been proposed, including differential erosion of channel sands compared to cohesive floodplain deposits, relative ease of flow through pre-defined relict channel paths, and gradients created by leftover topographic depressions from previous channels. However, the role of sea-level induced incision in channel reoccupation has not yet been fully explored beyond the timescale of initial channel trapping during lowstand. Here we present stratigraphic evidence that the Holocene Brahmaputra river system's recursive reoccupation behavior is dominated by the locations of valleys that were formed during the recent sea-level lowstand.

\subsection{Regional setting}

The Bengal basin, roughly coincident with the country of Bangladesh, is situated $\sim 200 \mathrm{~km}$ south of the Himalayan Arc and is bordered to the north by the recently-uplifted the Shillong Massif, to the west by the Indian Shield, and to the east by the Indo-Burman Fold Belt (Fig. 2). Three major rivers, the Ganges, the Brahmaputra, and the Meghna, drain the basin, which accommodates almost half of the sediments shed from the Himalaya collision (Métivier et al., 1999). After draining Himalayan bedrock, the Ganges and Brahmaputra rivers traverse alluvial plains before converging in the central Bengal basin and joining with the Meghna River before discharging into the Bay of Bengal.

Upstream of the Tista River, the mainstem Brahmaputra is fed by catchment rainfall and snowmelt. It acquires $~ 35 \%$ of its sediment load from the Namche Barwa and Great Bend gorge along the Himalayan syntaxis between Tibet and Assam, and $\sim 5 \%$ from the remaining Tibetan landscape; 14\% comes from the Lohit River and Mishmi Hills and 25\% comes from the Siang River, of Arunachal Pradesh, India; other Himalayan tributaries contribute another 14\%; and 7\% comes from the Shillong Massif and Indo-Burman ranges bordering Bangladesh (Garzanti et al., 2004) (Fig. 2). The Tista River is the Brahmaputra's largest Himalayan tributary, joining the main channel about $20 \mathrm{~km}$ north of the Jamuna-Old Brahmaputra avulsion node in the northern Bengal basin (Fig. 1).

Inside the Bengal basin the modern Brahmaputra-Jamuna has a braided planform with some vegetated and populated "chars", or island bars within the braidbelt that persist over decadal timescales (Best et al., 2007). The riverbanks comprise 60\% sand and $~ 40 \%$ silt and are highly susceptible to erosion (Thorne et al., 1993). Baki and Gan (2012) estimate bank-erosion rates up to $\sim 200 \mathrm{~m} / \mathrm{yr}$ between 1953 and 1989, reflecting great lateral mobility of the modern channel braidbelt, which is up to $18 \mathrm{~km}$ wide and comprises 90\% sand and $\sim 10 \%$ silt on the chars.

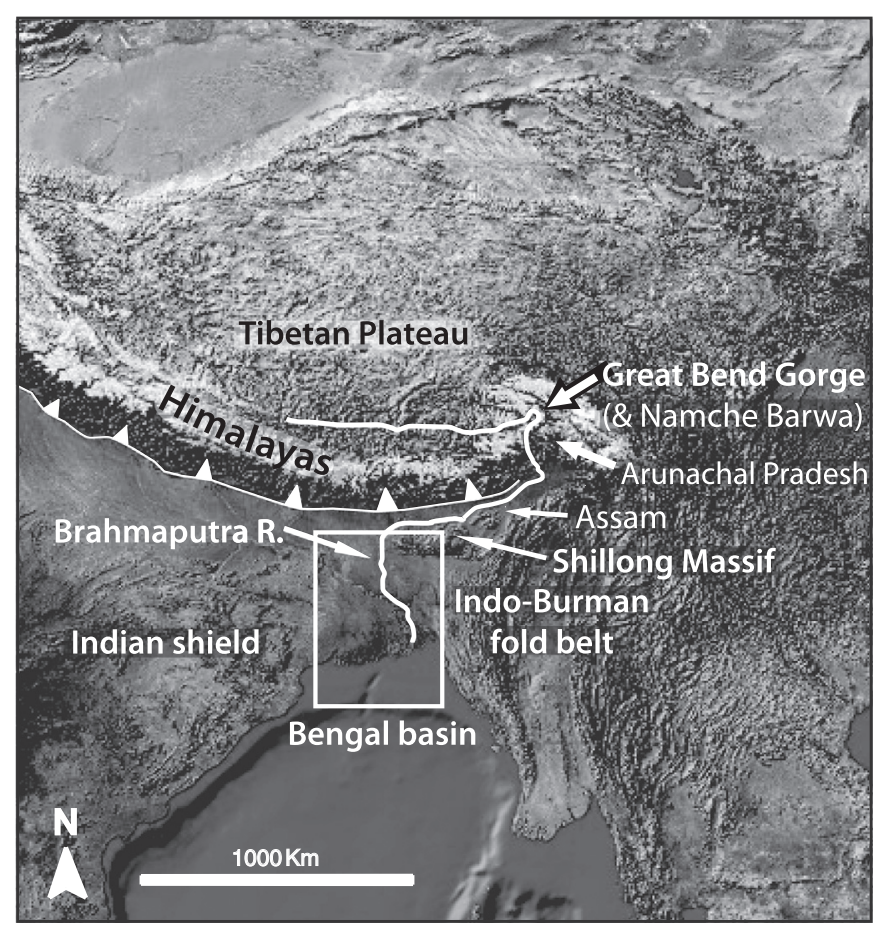

Fig. 2. Regional setting of South Asia showing shaded-relief topography and course of the Brahmaputra River. The Bengal basin is approximated by the boxed area. Base image from WorldSat@.

\subsection{The historical Brahmaputra avulsion}

During the late eighteenth to early nineteenth century the Brahmaputra River avulsed at a site near the modern Tista-Brahmaputra confluence (Fig. 1). This avulsion has been attributed to a variety of triggers including a natural diversion of the upstream Tista River into the Brahmaputra River (Morgan and McIntire, 1959), faulting and structural control (Coleman, 1969), and gradual tectonic basin tilting (e.g., Kim et al., 2010). For detailed accounts of the avulsion see Bristow (1999), Sarker et al. (2003), and Best et al. (2007).

Regardless of its cause, the avulsion of the Brahmaputra diverted the majority of the river's flow into the modern course west of the Madhupur Terrace and today leaves a relatively small meandering channel within the braidbelt of the Old Brahmaputra course (Fig. 3). This partial avulsion has resulted in the Old Brahmaputra channel becoming a small distributary of the main Brahmaputra-Jamuna system (cf., Slingerland and Smith, 2004). Such behavior may be typical of river course changes in the Bengal basin, because the large river discharge and high local rainfall are effective at maintaining flow through distributary channels for relatively long periods of time. A pattern of prolonged partial avulsions may also complicate how avulsion and course changes are recorded in the stratigraphy. However, by identifying the source, lithology, and distribution of sediments built by these distributary channels, it is possible to infer the avulsion behavior of the Brahmaputra and the processes that have constructed the upper Bengal delta plain through the Holocene.

\section{Methods}

Motivated by the historic diversion of the Brahmaputra River, boreholes were sited along a transect (Transect A) that spans the full width of the Brahmaputra-Jamuna and Old Brahmaputra valleys downstream of the avulsion node, as well as the terraced and elevated surfaces that flank these valley systems (Fig. 3). Transect A comprises 41 boreholes spaced $\sim 3 \mathrm{~km}$ apart over a $120 \mathrm{~km}$ distance, beginning on an outcropping terrace near the city of Bogra, which is the easternmost exposure of the 

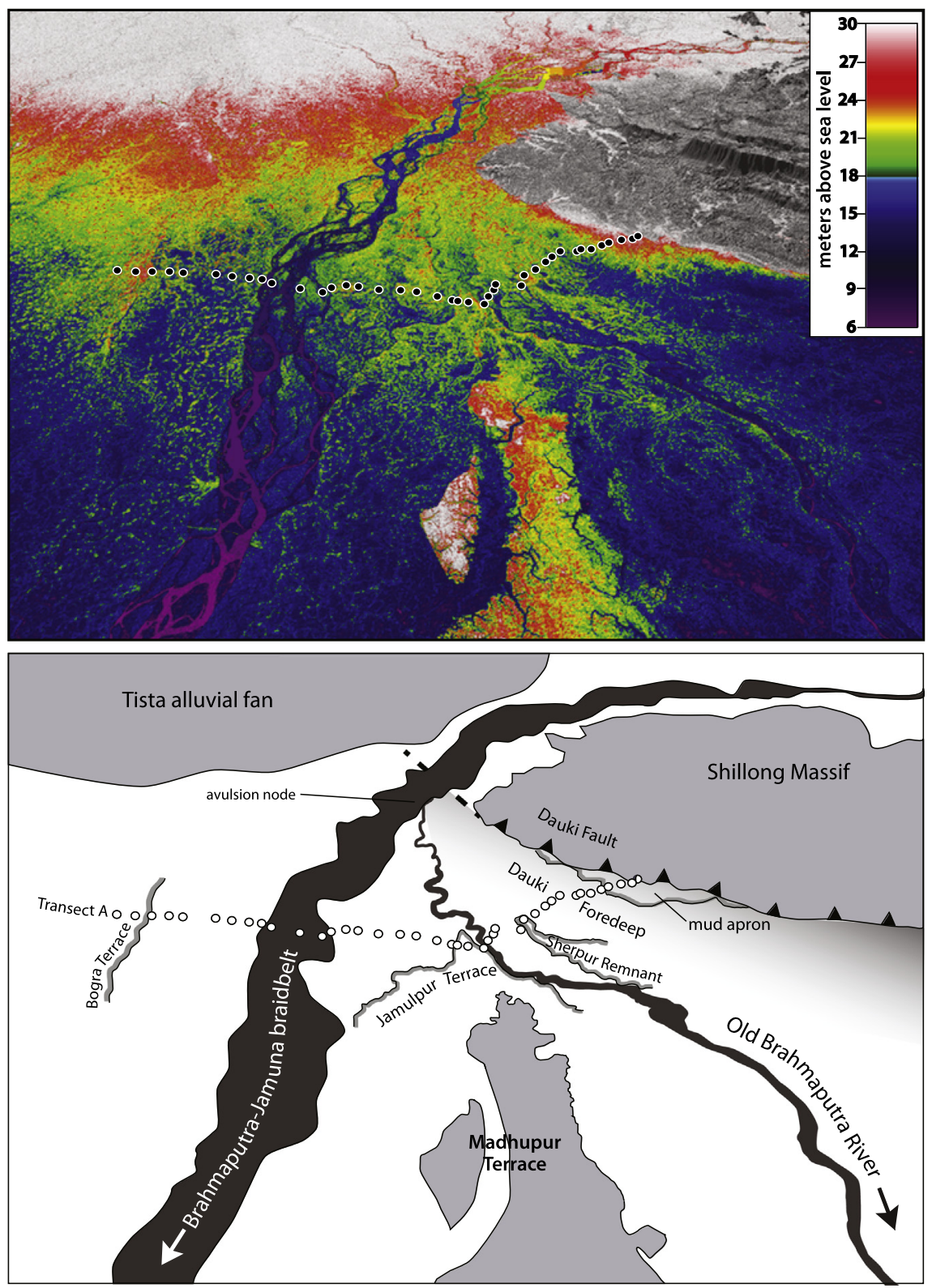

Fig. 3. Oblique view of a DEM of the study area (top) and annotated physiography (bottom). The circles in both figures represent borehole locations of Transect A.

Pleistocene Barind Tract, and ending at low-lying Neogene to Quaternary hills near the base of the Shillong Massif. The depth of drill core recovered at each site ranged from 20 to $91 \mathrm{~m}$ below the surface, with a mean core length of $55 \mathrm{~m}$. In total, $2255 \mathrm{~m}$ of sediment were extracted among the 41 drill sites.

Drilling was accomplished using a local reverse-circulation, fulcrumand-lever method that was designed to install tubewells for drinking water. The drill fluid is a mixture of water and organic filling material to generate lift, and when coupled with $\sim 20 \mathrm{~cm} / \mathrm{sec}$ vertical flow rates, the drilling process is sufficiently competent to extract gravel, wood, and soil concretions up to the full 5-cm diameter of the PVC pipes. The foot of the drill string is capped with a $10-\mathrm{cm}$ steel cutting shoe that is capable of scouring consolidated clays and fracturing concretions and gravel clasts.

Samples were collected as wash borings at $1.5 \mathrm{~m}$ intervals. At each interval $\sim 1 \mathrm{~kg}$ of extruded sediment was captured ( $20 \mathrm{~cm}$ section), from which $\sim 200 \mathrm{~g}$ were preserved for analyses. Samples were also collected between intervals where a significant change in lithology was observed. For sandy deposits, the drill fluid was decanted from the disaggregated sands; with $\sim 1 \mathrm{~kg}$ of sample recovered, though, there does not appear to be any significant bias introduced in the decanting process. For muddy deposits, these cohesive sediments were extruded as consolidated, coherent plugs (often with bedding preserved) that were readily separated from the drill fluid.

At most sites, drilling depth was limited by the loss of daylight, as the drill hole collapsed if not continually drilled. However, drilling at some sites stopped because the coring processes could not penetrate the underlying strata, often with gravel being returned in the sample or as a clast lodged in the drill tip. Therefore, we consider that wherever this 'depth of refusal' was encountered in this transect, it represents a consolidated, clast-supported gravel surface. Such a surface has been previously identified as a lowstand lag surface of boulders and cobbles within the Brahmaputra-Jamuna valley (e.g., Japan International Cooperation Agency, 1976; Goodbred and Kuehl, 2000). Shallower gravel beds also appear to have locally restricted drilling depths at some borehole sites along the transect.

At the time of sampling, field descriptions of grain size, color, and the presence of gravel and organic material were determined and logged. In 
the lab, laser-diffraction particle size analysis from $0.0005-1.168 \mathrm{~mm}$ was performed on all samples to 20-m depth and every other sample (i.e., 3-m interval) below $20 \mathrm{~m}$ using a Malvern Mastersizer 2000E. Samples were prepared for analysis by sieving to remove the sediment fraction $>1.168 \mathrm{~mm}$ in accordance with the measurement capabilities of the instrument, and the lithology of these larger grains was described in hand sample. In total, 980 samples were analyzed and results are reported here as volume-weighted mean diameter. Bulk major and trace element concentrations were also measured on alternating samples from every other borehole, with more dense sampling in areas of interest. In total 444 samples were geochemically analyzed by Xray fluorescence (XRF) using either a benchtop Oxford Instruments MDX 1080 + XRF Spectrometer for bulk geochemistry or a handheld Thermoscientific Niton XL3 Analyzer for more rapid targeted assessment of strontium $(\mathrm{Sr}$ ) concentrations. We emphasize $\mathrm{Sr}$ because it has been a useful discriminator for determining provenance of fluvial sediments in the Brahmaputra River (e.g., Singh and France-lanord, 2002; Goodbred et al., in press). Bulk magnetic susceptibility (MS) is likewise a useful tool for determining provenance of sediments in large river systems (e.g., Maher et al., 2009; Zhang et al., 2008), and we measured 1521 sediment samples using a Bartington Magnetic Susceptibility Meter point counter.

Twenty-one AMS radiocarbon dates were obtained by the National Ocean Sciences Accelerator Mass Spectrometry Facility (NOSAMS) at the Woods Hole Oceanographic Institution from plant and wood material or from the total organic carbon (TOC) content of fine-grained sediments. All radiocarbon ages were calibrated using CALIB 6.0 software (Stuiver and Reimer, 1993) with the intcal09. ${ }^{14} \mathrm{C}$ terrestrial calibration curve. Ages in this text are reported in calibrated sidereal years (cal BP). Wherever possible, radiocarbon dates were made on organic matter recovered 'in situ' from coherent mud plug samples. However, owing to the dominance of sandy stratigraphy with little datable material along the transect, some radiocarbon samples recovered from sandy lithology may be vertically displaced by a few meters (i.e., an error of $\sim 10 \%$ of total depth).

\section{Results}

\subsection{Grain size and lithology}

Particle size results reveal a generally sandy stratigraphy across the transect, with a small fraction of mud preserved (Figs. 4, 6) primarily near the surface and locally close to the Shillong Massif (Fig. 5). The ratio of mud to sand typically does not comprise more than $20 \%$ of the stratigraphy at any particular location (Fig. 6), with the exception of old terraced interfluves and basin settings (i.e., Bogra and Jamulpur
Terraces and the Dauki Foredeep). Within the sand-dominated stratigraphy, gravel clasts are present in $~ 10 \%$ of samples, comprising a small but widespread component of preserved sediment (Fig. 5).

Grain-size trends at most locations generally fine upward, with basal deposits typically comprising medium to coarse sand and decreasing to fine sand in the upper stratigraphy (Fig. 5). The mean grain size of nearsurface deposits $(<10 \mathrm{~m})$ includes silt-dominated muds and very fine sands along the interfluve margins, coarsening to fine or medium sand within the central portion of the river valleys. In general mud is not preserved below $10-20 \mathrm{~m}$, except for the thick mud (20-50 m) sequences near the Shillong Massif (Fig. 5; BNGA110-123). In contrast, coarse sand and gravel is preferentially preserved in the deeper stratigraphy and rarely found shallower than $20 \mathrm{~m}$ below surface.

For the sand-dominated lithologies, the grain-size distributions are well sorted with rounded grains, gray to gray-brown in color, and composed primarily of quartz and feldspar with generally abundant micas and heavy minerals. However, there is a distinctive sand lithology that occurs as discrete deposits within the mud-dominated stratigraphy near the Shillong Massif. These unique sands comprise poorly sorted, angular, quartz grains with an orange Fe-oxide coating. The mud-dominated sediments recovered along the transect exhibit highly variable color including orange, gray, brown, olive, and nearly black. These fine sediments also have varying degrees of plasticity related to the nature and magnitude of pedogenic weathering they have experienced. This variable plasticity is locally useful in distinguishing relative age and serves as a marker for the LPSL exposure surface.

\subsection{Geochemical analyses}

From the bulk elemental geochemistry measured, patterns of bulk $\mathrm{Sr}$ concentration are useful in distinguishing populations of sediment that share a common provenance. Strontium isotopes have been well established as a useful provenance indicator for sediment derived from the Brahmaputra catchment (e.g. Singh and Francelanord, 2002). Here Sr concentrations are sufficient to distinguish Brahmaputra sediments derived from comparatively Sr-rich Tibet $(>140 \mathrm{ppm}$ ) from Sr-depleted terranes of the Himalaya and the Shillong Massif ( $<90 \mathrm{ppm})$ (cf. Goodbred et al., in press). Three general sediment populations emerge from the distribution of $\mathrm{Sr}$ concentrations (Fig. 7), including a low-Sr group (<90 ppm), an intermediateSr group (90-140 ppm), and a high-Sr group (>140 ppm). Among all samples measured, 67\% yielded $\mathrm{Sr}$ concentrations $>140 \mathrm{ppm}$ (high-Sr group) and correspond to Brahmaputra derived sediments. Among the remaining samples, $15 \%$ had low $\mathrm{Sr}(<90 \mathrm{ppm})$ and $18 \%$ had intermediate $\mathrm{Sr}$ concentrations. The low-Sr samples are located almost exclusively at the western and eastern boundaries of the core transect and appear to
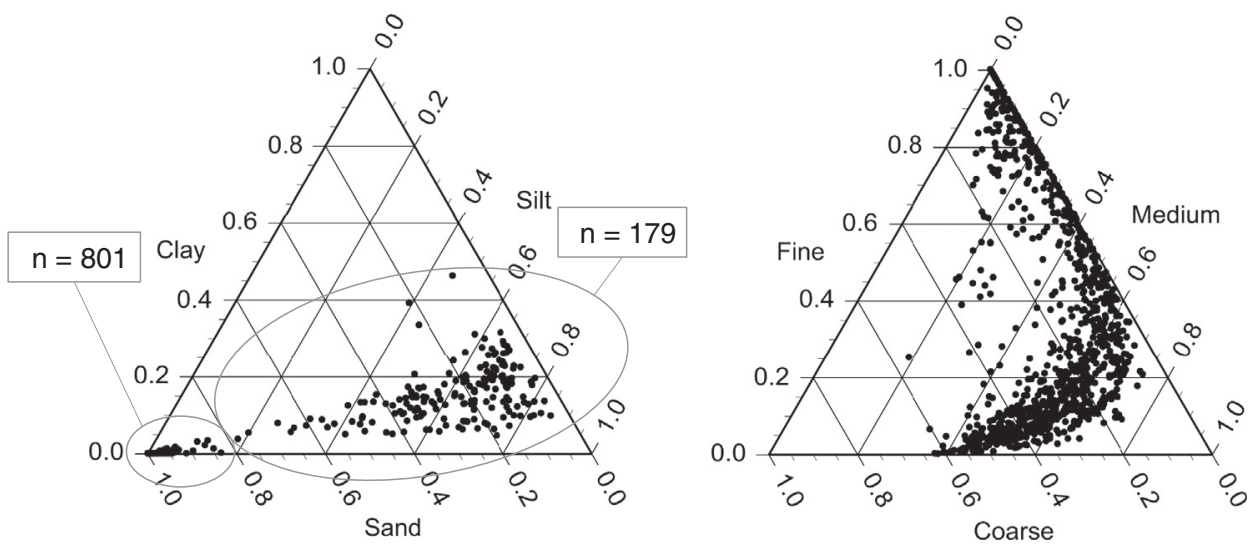

Fig. 4. Grain size distribution of all samples (left) and of the sand fraction for all samples (right). 


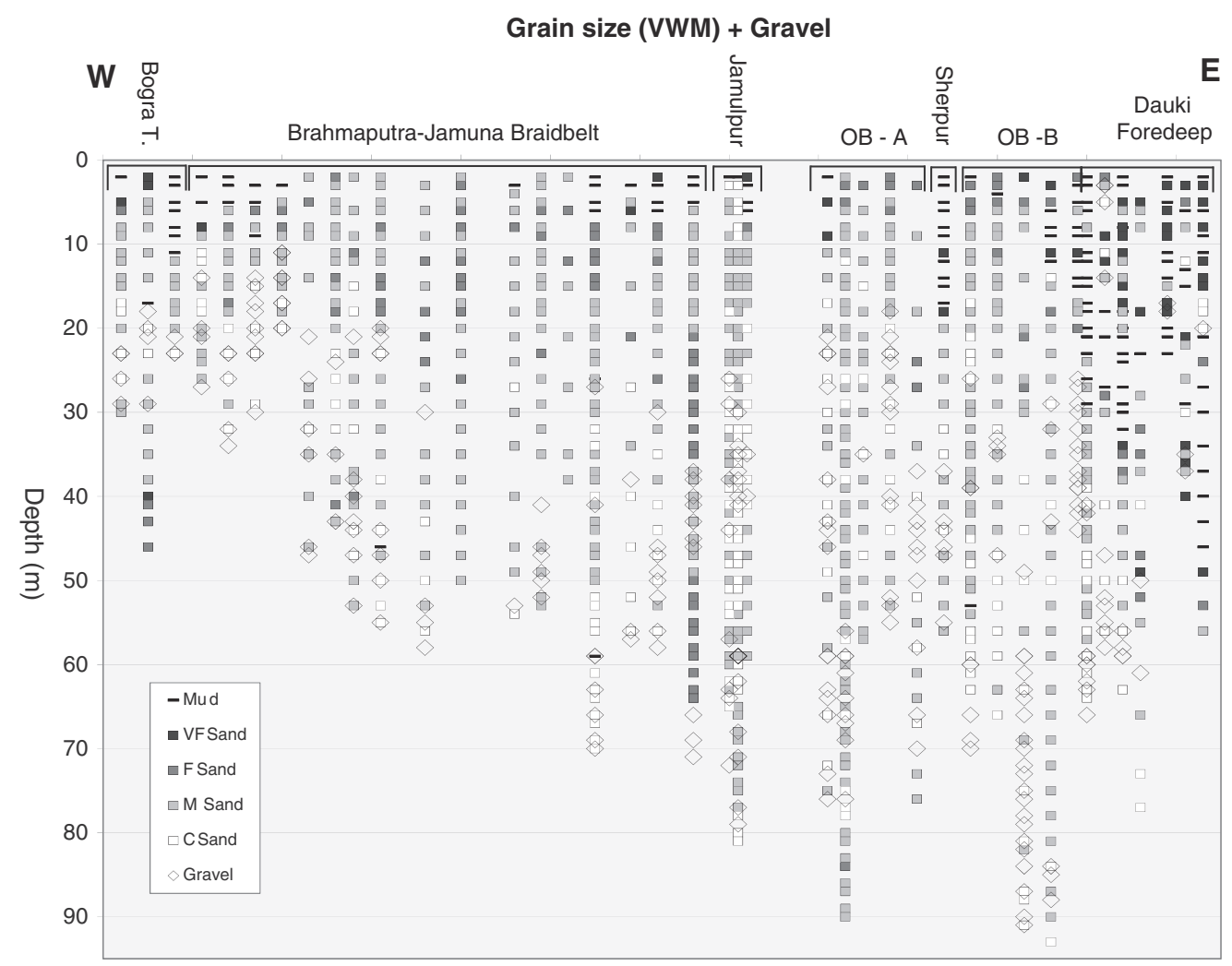

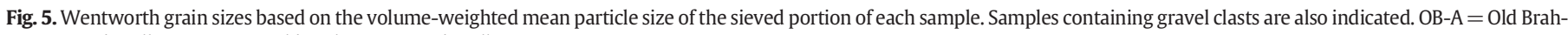
maputra sub-valley A; OB-B = Old Brahmaputra sub-valley B.

indicate Himalayan-derived sediments from the Tista River and local Shillong-derived stream sources, respectively (Fig. 7). Sediments having intermediate $\mathrm{Sr}$ concentrations are inferred to represent admixtures of these end-member sources.

\section{Lithofacies}

Sediments from the north-central Bengal basin are readily grouped into four principal lithofacies defined by their primary attributes, including volume weighted mean (VWM) grain size, bulk $\mathrm{Sr}$ concentration, presence of gravel, and the plasticity of mud lithologies. The emerging facies include those found in the Brahmaputra valleys, including Braidbelt Sands and Overbank Muds, and those found in the

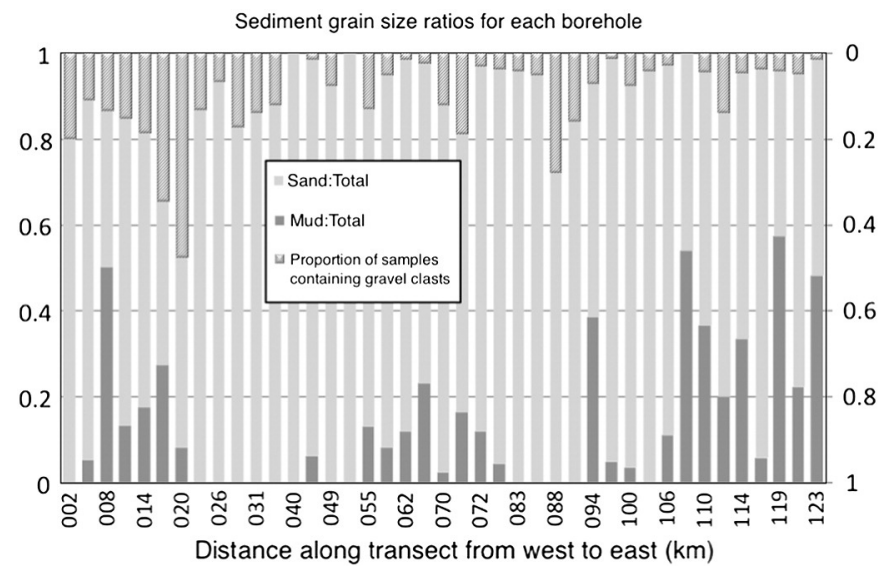

Fig. 6. Fraction of mud and sand in each borehole with the proportion of sand samples that also contain gravel clasts.
Dauki Foredeep, including Basinal Muds and Shillong Alluvium (Table 1; Fig. 8; cf. Goodbred and Kuehl, 2000).

\subsection{Brahmaputra Valley facies}

\subsubsection{Braidbelt Sands}

Among all lithofacies, the Braidbelt Sands are by far the most abundant and widespread deposits, accounting for $84 \%$ of all samples. These deposits comprise clean very fine-to-coarse quartz sands (mean 76-657 $\mu \mathrm{m}$ ) with abundant micas and heavy minerals and some feldspars. The sands are generally gray or gray-brown in color but may be mildly oxidized to slight orange or tan at depth in some areas, indicating brief intervals (102 years) of near-surface exposure and vadose-zone weathering. The Braidbelt Sands also have characteristically high $\mathrm{Sr}$ concentrations (>140 ppm) that reflect the Brahmaputra River as their dominant source. These deposits have locally lower Sr values (120-140 ppm), particularly near the western portion of the transect where the Tista River locally contributes low-Sr sands to the main Brahmaputra load (Fig. 7).

The Braidbelt Sands can be divided into Holocene and Pleistocene sub-facies. However, these sandy deposits do not preserve welldefined paleosols as do the mud facies, and so distinguishing Holocene and Pleistocene aged Braidbelt Sands is not as definitive as in the mud facies. In many instances, the Pleistocene-Holocene distinction was readily defined by radiocarbon dates, allowing us to identify several lithological attributes typically associated with the Pleistocene-age deposits. These include the higher occurrence of gravel and dried-mud clasts in Pleistocene sands and their coarser mean grain size ( $447 \mu \mathrm{m}$ compared to $378 \mu \mathrm{m}$ for the Holocene sands). Notably, high-Sr (>140 ppm), Pleistocene-age Braidbelt Sands also underlie the thick Basinal Muds near the Shillong Massif, indicating that the Brahmaputra River has previously occupied positions considerably closer to the modern Dauki Fault than it has in the Holocene (Fig. 7). 


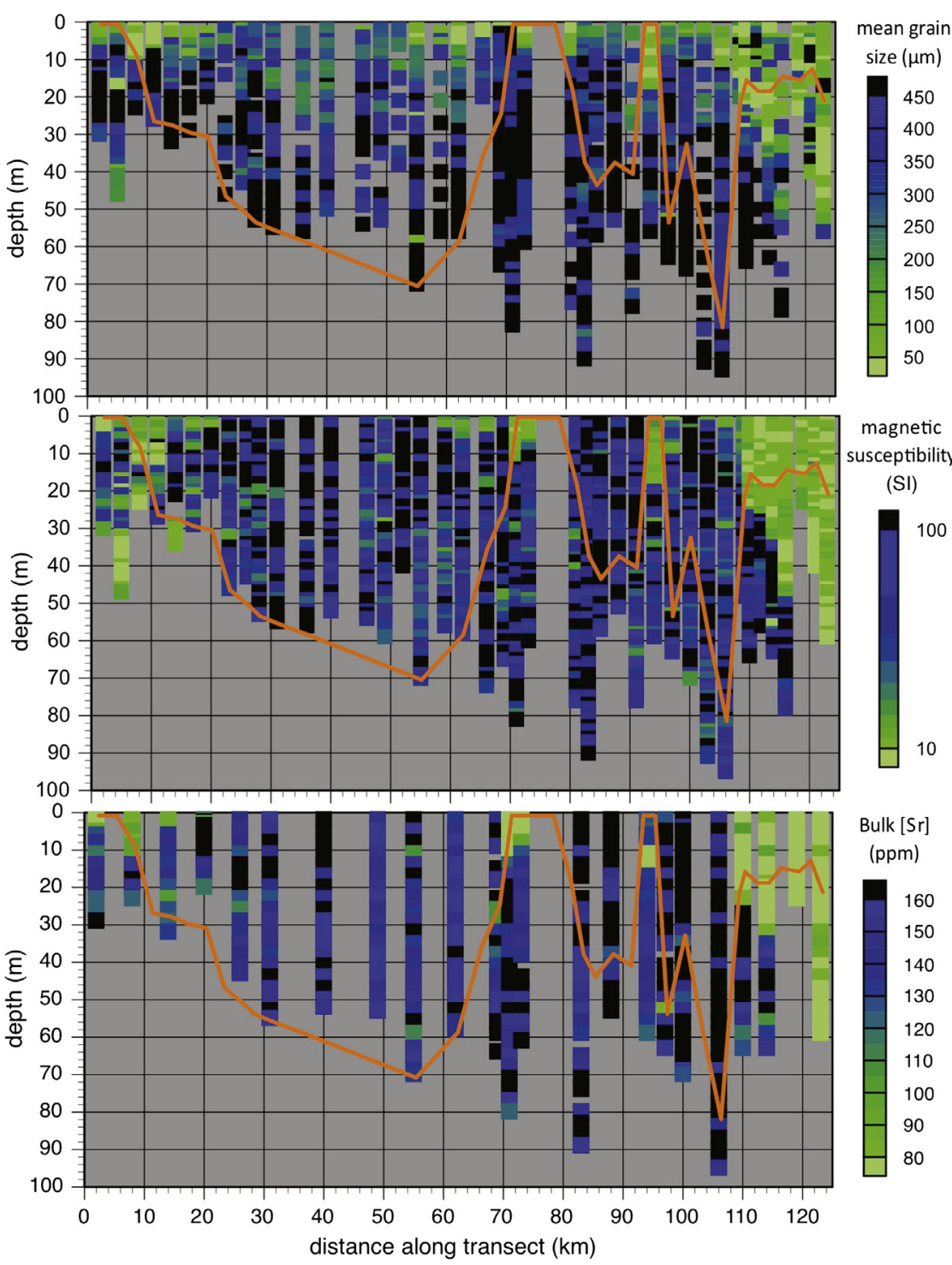

Fig. 7. Mean grain size, magnetic susceptibility, and bulk strontium intensity plots for selected samples. The orange line represents Pleistocene-Holocene stratigraphic contact.

\subsubsection{Overbank Muds}

Locally capping the Braidbelt Sands, the Overbank Mud facies is distinguished as brown silts $(20-80 \mu \mathrm{m})$ that occur as relatively thin (typically $\sim 5 \mathrm{~m}$ ), shallow ( $<10 \mathrm{~m}$ depth) deposits along the margins of the principal river valleys (Table 1; Fig. 8). These deposits represent fine-grained overbank deposition associated with the area's sandy braided rivers, principally the Brahmaputra. The facies is thin relative to typical channel depths and resulting thalweg and bar deposits (15-25 m), thus they have little chance for stratigraphic preservation despite being widely deposited (Goodbred and Kuehl, 2000). Indeed, only sparse remnants of Overbank Muds were recovered within the sandy subsurface stratigraphy of the main fluvial valleys, above $60 \mathrm{~m}$ depth (Fig. 8).

Two sub-units of this facies are defined as Holocene-age Overbank Muds (HOM) and Pleistocene-age Overbank Muds (POM), which can be consistently distinguished by their rheological properties. The HOM sediments comprise soft, deformable muds, whereas those of the POM are much stiffer and are extruded from the drill pipe as undeformed, cylindrical plugs of sediment. Based on radiocarbon dates, the soft, highly plastic muds correspond with strata deposited during the Holocene, whereas the undeformed, low-plasticity muds were deposited at least 48,000 yr BP (i.e., they contain radiocarbon-dead organic material).
The low-plasticity POM deposits include a paleosol that typically has a gray soil matrix (redox depletions) with prominent orange mottling associated with iron oxide formation, typified as a poorly drained gleysol (Brammer and Brinkman, 1977). This paleosol generally occurs within the upper 5-10 m of the POM deposits. The extent of chemical weathering, i.e. oxidation, and compaction that these muds have undergone indicates exposure during a sea-level lowstand, presumably the last lowstand of the late Pleistocene. In terms of lithology the Holocene and Pleistocene Overbank Muds share similar mean grain sizes ( $44 \mu \mathrm{m}$ and $37 \mu \mathrm{m}$, respectively), but are generally geochemically distinct. Strontium concentrations in the HOM sub-facies are typically $>140 \mathrm{ppm}$, except for the Tista-influenced muds from the western transect, which are $<120$ ppm. By comparison, strontium concentrations in the POM subfacies are predominantly $<120$ ppm (Fig. 7).

\subsection{Dauki Foredeep Facies}

Although Brahmaputra-deposited sediments extend into Sylhet basin through the Old Brahmaputra valley, locally sourced sediments also comprise a considerable portion of the stratigraphy in the Sylhet 
Table 1

Facies descriptions of sediments recovered from Transect A.

\begin{tabular}{|c|c|c|c|c|c|c|c|}
\hline Facies & Lithology & Sr concentration & $\begin{array}{l}\text { Spatial } \\
\text { distribution }\end{array}$ & Thickness & Depth to top & $\begin{array}{l}\text { Period of } \\
\text { deposition }\end{array}$ & Interpretation \\
\hline $\begin{array}{l}\text { Holocene } \\
\text { Braidbelt Sands }\end{array}$ & $\begin{array}{l}\text { Clean, quartz-rich } \\
\text { very fine to coarse } \\
\text { sands; typically } \\
\text { gray or gray-brown } \\
\text { in color: gravel }\end{array}$ & \multirow[t]{2}{*}{$\begin{array}{l}\text { Generally }>140 \\
\text { ppm; } 120-140 \text { ppm } \\
\text { not uncommon }\end{array}$} & \multirow{2}{*}{$\begin{array}{l}\text { Widespread in } \\
\text { paleovalleys } \\
\text { Widespread below } \\
\text { paleovalleys, mud- } \\
\text { capped features, } \\
\text { and Dauki foredeep }\end{array}$} & \multirow[t]{2}{*}{$\begin{array}{l}\text { Up to } 80 \mathrm{~m} \text { thick in } \\
\text { deepest parts of } \\
\text { valleys }\end{array}$} & $0-80 \mathrm{~m}$ & Holocene & \multirow[t]{2}{*}{$\begin{array}{l}\text { Alluvial deposits of } \\
\text { the Brahmaputra } \\
\text { (valley fill) }\end{array}$} \\
\hline Braidbelt Sands! & $\begin{array}{l}\text { in color; gravel } \\
\text { often present }\end{array}$ & & & & $15-95 \mathrm{~m}$ & $\begin{array}{l}\text { Pre-Holocene } \\
\text { (Late Pleistocene) }\end{array}$ & \\
\hline $\begin{array}{l}\text { Holocene Overbank } \\
\text { Muds }\end{array}$ & Thin silt deposits & $\begin{array}{l}\text { Typically }>140 \mathrm{ppm} \\
\text { but } 120-140 \mathrm{ppm} \\
\text { notuncommon; } \\
\text { occasionally } ~ 90 \\
\text { ppm in Bogra Terrace }\end{array}$ & $\begin{array}{l}\text { Shallow subsurface } \\
\text { at valley margins; } \\
\text { occasional localized } \\
\text { deposit at depth }\end{array}$ & $\begin{array}{l}\text { Typically } \sim 5 \mathrm{~m} \text {; } \\
\text { localized deposits } \\
\text { are } \sim 1 \mathrm{~m} \text { at depth }\end{array}$ & $\begin{array}{l}\text { Typically surface to } \\
<10 \mathrm{~m} \text { at valley } \\
\text { margins; few } \\
\text { locally at depth }\end{array}$ & $\begin{array}{l}\sim 10,000 \text { BP to } \\
\text { present }\end{array}$ & $\begin{array}{l}\text { Modern and } \\
\text { preserved overbank } \\
\text { deposits }\end{array}$ \\
\hline $\begin{array}{l}\text { Pleistocene } \\
\text { Overbank Muds }\end{array}$ & $\begin{array}{l}\text { Generally stiff silts } \\
\text { often underlain by } \\
\text { silts; typically gray } \\
\text { matrix with orange } \\
\text { mottling }\end{array}$ & $\begin{array}{l}\text { Generally }<120 \\
\text { ppm; up to } 140 \text { ppm } \\
\text { in core } 094\end{array}$ & $\begin{array}{l}\text { Prevalent in shallow } \\
\text { subsurface of valley } \\
\text { margins and upper } \\
\sim 20 \text { mof core } 094\end{array}$ & $\begin{array}{l}\text { 1-20 m; typically } \\
\sim 5-10 \mathrm{~m}\end{array}$ & Surface to $\sim 55 \mathrm{~m}$ & $\begin{array}{l}\text { Pre-Holocene } \\
\text { (Late Pleistocene) }\end{array}$ & $\begin{array}{l}\text { Overbank deposits } \\
\text { with well-developed } \\
\text { paleosols }\end{array}$ \\
\hline $\begin{array}{l}\text { Holocene Basinal } \\
\text { Muds }\end{array}$ & $\begin{array}{l}\text { Soft silts of varying } \\
\text { color }\end{array}$ & \multirow[b]{2}{*}{$\begin{array}{l}\text { Consistently <90 } \\
\text { ppm; often }<70 \text { ppm }\end{array}$} & $\begin{array}{l}\text { Locally in cores } \\
109-123\end{array}$ & $\begin{array}{l}\text { Generally } 15-20 \mathrm{~m} \text {, } \\
\text { with interspersed } \\
\text { sands in some cores }\end{array}$ & $0-20 \mathrm{~m}$ & Holocene & \multirow[b]{2}{*}{$\begin{array}{l}\text { Dauki foredeep } \\
\text { deposits }\end{array}$} \\
\hline $\begin{array}{l}\text { Pleistocene } \\
\text { Basinal Muds }\end{array}$ & $\begin{array}{l}\text { Generally stiff silts; } \\
\text { stiffness decreases } \\
\text { with depth below } \\
\text { weathering horizon }\end{array}$ & & $\begin{array}{l}\text { Locally in cores } \\
110-123\end{array}$ & $\begin{array}{l}\text { Up to } 40 \mathrm{~m} \text { with } \\
\text { interspersed sands }\end{array}$ & $10-60 \mathrm{~m}$ & Pleistocene & \\
\hline Shillong Alluvium & $\begin{array}{l}\text { Angular,poorly } \\
\text { sorted, generally } \\
\text { quartz-rich coarse } \\
\text { sands and granules }\end{array}$ & $<90 \mathrm{ppm}$ & $\begin{array}{l}\text { Locally in cores } \\
109-123 \text { (Dauki } \\
\text { foredeep) }\end{array}$ & $<10 \mathrm{~m}$ & $2-55 \mathrm{~m}$ & $\begin{array}{l}\text { Pre-Holocene to } \\
\text { recent }\end{array}$ & $\begin{array}{l}\text { Shillong-sourced } \\
\text { ephemeral stream } \\
\text { deposits }\end{array}$ \\
\hline
\end{tabular}

basin area, particularly along the northern flank of the Dauki Foredeep, within $10-15 \mathrm{~km}$ of the Dauki Fault and the Shillong Massif.

\subsubsection{Basinal Muds}

This fine-grained facies defines a lithologically and morphologically unique wedge-shaped deposit in the Sylhet basin that thickens from $25 \mathrm{~m}$ to $>60 \mathrm{~m}$ towards the Shillong Massif (BNGA110-123; Fig. 8). The thickness of these deposits is one of the principal attributes distinguishing this facies from the comparatively thin $(<10 \mathrm{~m})$ Overbank Muds. Overall the deposition of this facies reflects long-term mud accumulation in the northern flank of the subsiding Dauki Foredeep basin, which is being overthrust along the Dauki Fault (Fig. 1). These Basinal Muds are further distinguished from the Overbank Muds by their almost uniformly low $\mathrm{Sr}$ concentrations $(<70 \mathrm{ppm})$ and magnetic susceptibility $(<10 \mathrm{SI}$ ), which reflect their local sourcing from the Shillong Massif (Fig. 7). The Basinal Muds are further distinguished into Holocene and Pleistocene sub-facies based on radiocarbon ages and their distinctive rheologies-high-plasticity Holocene-age muds and low-plasticity Pleistocene paleosols. Otherwise the two Basinal Mud sub-facies are lithologically similar and have a mean grain size $\sim 50 \mu \mathrm{m}$ and similar range of colors and oxidation state.

\subsubsection{Shillong Alluvium}

In contrast to the well-rounded, well-sorted Braidbelt Sands associated with the Brahmaputra River, the Shillong Alluvium consists of angular, poorly sorted, often coarse sand and granules to gravels. The size fraction $>1.1 \mathrm{~mm}$ often contributes $>50 \%$ of the facies by weight, and the remaining portion sieved for laser-diffraction size analysis $(<1.1 \mathrm{~mm})$ yielded a mean grain size of $330 \mu \mathrm{m}$ with a range from 102 to $588 \mu \mathrm{m}$, but the bulk sample mean grain size is considerably larger. These sands are also quartz-enriched without the feldspars and heavy minerals that characterize the Braidbelt Sands. This unvarying mineral assemblage is reflected in the low $\mathrm{Sr}$ concentrations (71-87 ppm) and very low MS values ( $<10 \mathrm{SI}$ ) (Fig. 7). Further distinguishing them from the thick, widespread braidbelt deposits, these sands occur only locally as thin units $(<10 \mathrm{~m})$ within the northward-thickening wedge of Basinal Muds near the DaukiFault (Figs. 1, 8). The Shillong Alluvium occurs both above and below the Holocene-Pleistocene boundary but without distinct variation and is therefore not subdivided by age. Nevertheless, the distinct lithology and local distribution indicate that these coarse alluvial units are splay and channel deposits of the small flashy streams that drain the steep, humid southern margin of the Shillong Massif.

\section{Morphostratigraphic Units}

Spatial distribution of the facies reveals two principal fluvial valleys, corresponding to the present day Brahmaputra-Jamuna and Old Brahmaputra river courses. These valleys are primarily bound by terraced interfluves, or locally by the Sylhet mud wedge in the east (Fig. 9). From these findings emerge five morphostratigraphic features that are distinguished both by their characteristic surface morphology and analogous subsurface stratigraphy. The surface morphology is revealed in digital elevation maps (Fig. 3) and satellite imagery and largely corresponds with the underlying stratigraphy. The morphostratigraphic units are, from west to east: the Bogra Terrace, the Brahmaputra-Jamuna Valley, the Jamulpur Terrace, the Old Brahmaputra Valleys, and the Dauki Foredeep (Fig. 3). Here we discuss the stratigraphy associated with these surficial geomorphic expressions.

\subsection{Bogra Terrace}

The Bogra Terrace lies along the eastern margin of the Barind Tract (Fig. 1). Located at the western edge of Transect A, this terraced deposit extends from BNGA002 to BNGA008 and lies 5-10 m higher than the adjacent Holocene floodplain (Fig. 3). This unit is composed of stiff, weathered Pleistocene Overbank Muds overlying shallow gravel-rich Braidbelt Sands (Fig. 8). Along the unit's boundary with the Brahmaputra-Jamuna Valley to the east, a thin unit of Holocene Overbank Muds locally caps it. Overall, the abundance of rounded gravels in both the weathered Pleistocene sediments and the Braidbelt Sands, in addition to the low to intermediate $\mathrm{Sr}$ values of the mud units and sand matrix reflect the strong influence of Tista River sediments. Indeed this area lies along the downdip boundary of the Tista River's alluvial megafan (DeCelles 


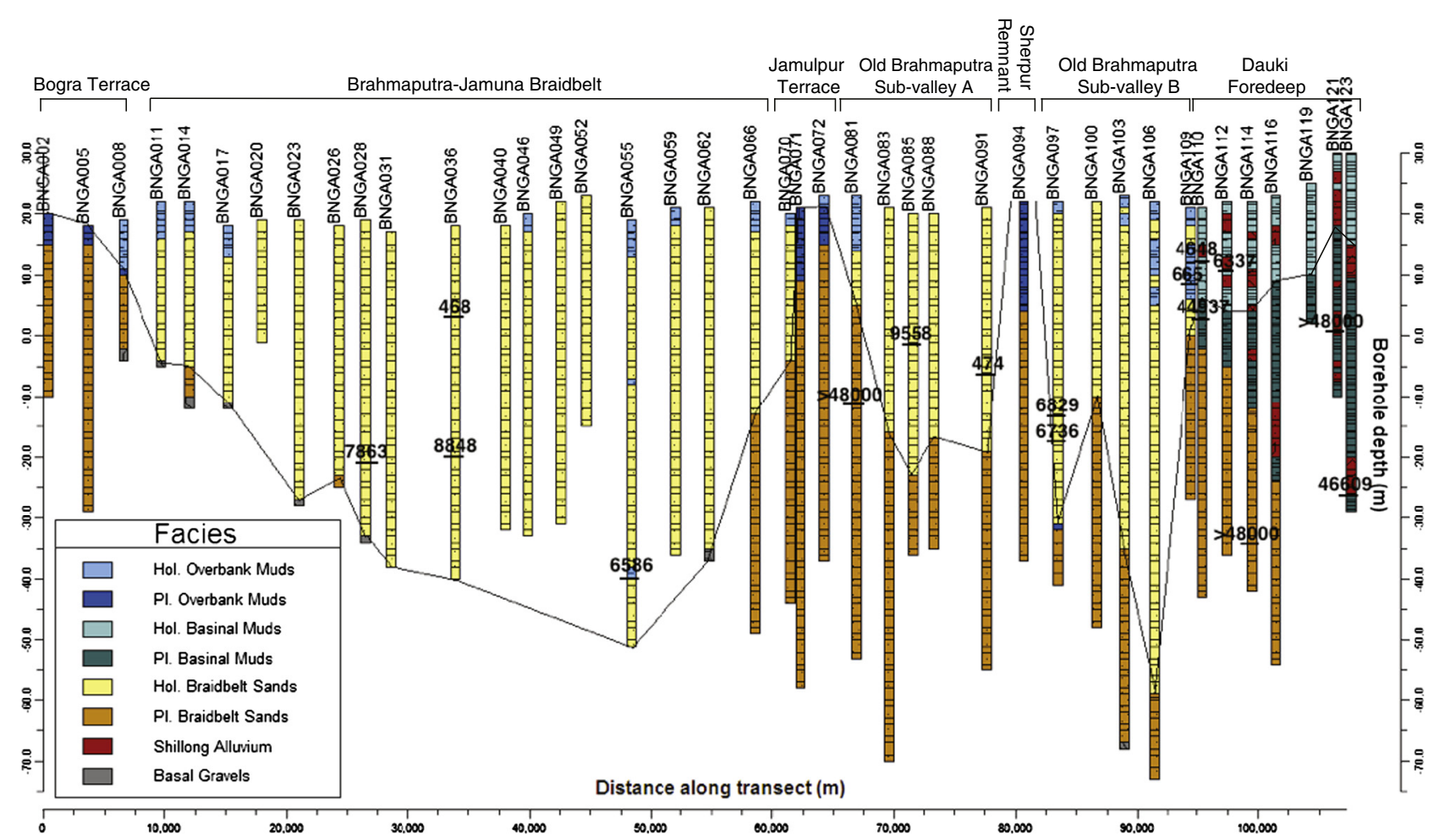

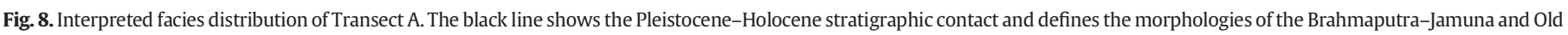
Brahmaputra valleys.

and Cavazza, 1999; Chakraborty and Ghosh, 2010) and represents a mixing zone of Barind-derived Tista sediments with sediments from the mainstem Brahmaputra River.

\subsection{Brahmaputra-Jamuna Valley}

The Brahmaputra-Jamuna River valley spans nearly $60 \mathrm{~km}$ from the Bogra Terrace (BNGA011) to the Jamulpur Terrace (BNGA070) (Fig. 8). The valley is filled almost entirely (93\%) with sandy sediments comprising thick (20-60 m) successions of Holocene Braidbelt Sands that generally fine upward (Fig. 6). These braidbelt deposits are typically capped at the surface by a thin $(<5 \mathrm{~m})$ unit of Overbank Muds, although such deposits are scarce below $10 \mathrm{~m}$ and found in only 2 of 19 cores drilled in this valley. This absence of mud preservation indicates a laterally mobile channel system that is effective at post-depositional reworking of nearsurface sediments. Within the Brahmaputra-Jamuna Valley, sediments are almost solely high-Sr (>140 ppm), with few samples yielding upper intermediate-Sr (120-140 ppm) signatures (Fig. 7). This geochemical homogeneity indicates that the mainstem Brahmaputra River has been the dominant fluvial system to construct the valley's stratigraphy throughout the Holocene.

\subsection{Jamulpur Terrace}

The Jamulpur Terrace is an elevated surface that lies $5-7 \mathrm{~m}$ above the adjacent Brahmaputra-Jamuna Valley and is comparable, if not correlative, with the Bogra Terrace (Fig. 3). The Jamulpur Terrace abuts the older, higher Madhupur Terrace that lies about $12 \mathrm{~km}$ to the southeast (Fig. 3; Morgan and McIntire, 1959; Umitsu, 1993; Rashid et al., 2006). Along Transect A, the Jamulpur Terrace serves as the interfluve between the two major channel pathways of the Brahmaputra River, separating the Jamuna and Old Brahmaputra valleys (Fig. 3). Stratigraphy of the Jamulpur terrace consists of a $10 \mathrm{~m}$ thick cap of Pleistocene Overbank Muds that overlies Pleistocene Braidbelt Sands and is fully preserved at core sites BNGA071 and 072. However, at sites BNGA070 and 081, lateral migration and erosion by the Brahmaputra during the Holocene has removed the capping mud unit, preserving only the lower gravelly sand stratigraphy of the Pleistocene sequence, which lies unconformably beneath a Holocene channel-floodplain succession (Fig. 8).

\subsection{Old Brahmaputra Valley}

The Old Brahmaputra Valley lies along the boundary of the Sylhet basin and spans $28 \mathrm{~km}$ along the eastern portion of Transect A (BNGA081-109). The valley system is situated between the Pleistocene Jamulpur terrace and the lithologically distinct Dauki Foredeep-related mud-wedge. The stratigraphy shows that this broad valley is actually a composite of two smaller valleys bifurcated around a remnant of the Jamulpur Terrace (BNGA094). Each of these Old Brahmaputra sub-valleys is only the width of the modern Brahmaputra braidbelt $(10-15 \mathrm{~km})$, or about $1 / 3$ that of the Brahmaputra-Jamuna valley (Fig. 9). These constrained dimensions for the Old Brahmaputra valley system are consistent with the abrupt and distinct changes in stratigraphy that occur along the valley margins, indicating sharply bound valley walls.

Sediments within the Old Brahmaputra sub-valleys are almost entirely Braidbelt Sands underlain by similar Pleistocene-age Braidbelt Sands. Like the Brahmaputra-Jamuna valley, these sediments also have high Sr values (>140 ppm) indicating a primarily Brahmaputra source (Fig. 7). Also similar to the Brahmaputra-Jamuna Valley, only $25 \%$ of boreholes collected within the Old Brahmaputra Valley preserved any Overbank Mud below $\sim 10 \mathrm{~m}$ depth. Compared with the Holocene valley depth in the much larger Brahmaputra-Jamuna system, the base of the Holocene sequence is shallower in the western sub-valley and slightly deeper in the eastern sub-valley of the Old Brahmaputra system. More distinctively, there is no evidence for the presence of a basal gravel unit flooring the valley system as there is in the Brahmaputra-Jamuna valley. This is not to say that gravels are not 


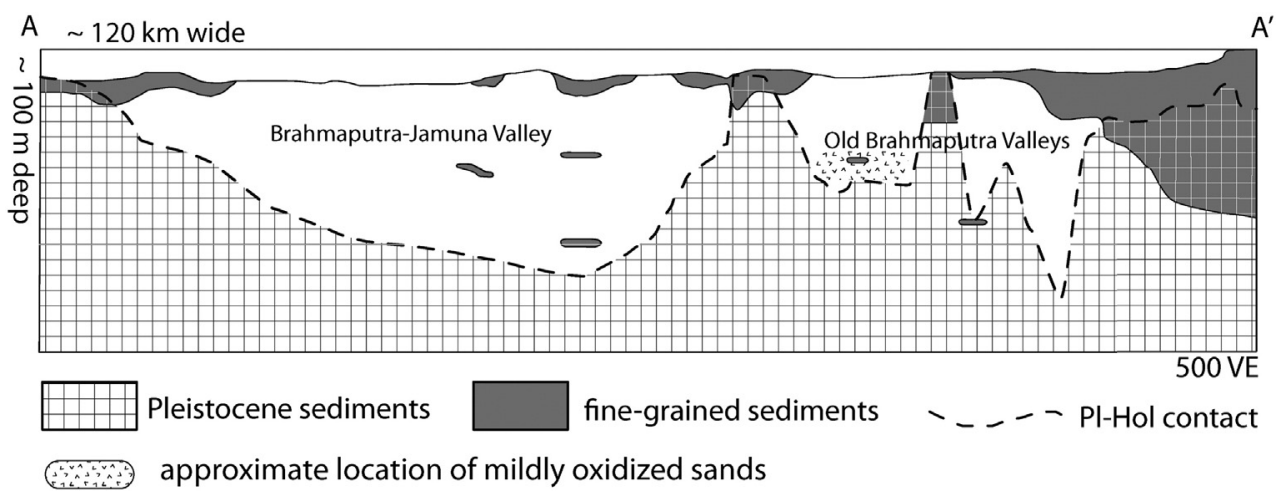

Fig. 9. Interpreted diagram of primary Brahmaputra River sediment-filled valley systems.

present in the sandy braidbelt matrix, only that there is no gravel bed that floors the valley, suggesting that the Brahmaputra River did not likely occupy its Sylhet basin course during the last lowstand of sea-level, an inference that is also consistent with the smaller valley dimensions.

Another unique attribute of the Old Brahmaputra valley stratigraphy is a slightly oxidized channel-floodplain succession in sub-valley A (Fig. 9). This $\sim 10 \mathrm{~m}$ thick deposit at a depth of $\sim 35 \mathrm{~m}$ below the surface comprises $<2$ m of Overbank Mud deposits overlying a unit of mildly oxidized, orange-tinted sands that we attribute to post-abandonment vadose zone weathering after an avulsion out of sub-valley A. These Holocene Braidbelt Sands are notably less oxidized than those of Pleistocene age, such as the thick Pleistocene sections underlying the Jamulpur Terrace, for example (Fig. 9). For comparison, exposed sands deposited by the Old Brahmaputra before abandonment during the late eighteenth to early nineteenth century avulsion have a similar degree of oxidation (cf. Chandina Alluvium; Alam et al., 1990).

\subsection{Dauki Foredeep}

The geomorphic expression of the northern flank of the Dauki Foredeep along Transect A is a relatively sloped piedmont surface (gradient $=1 \times 10^{3}$ compared to $5 \times 10^{5}$ for the delta plain) that lies up to $10 \mathrm{~m}$ higher than the adjacent Old Brahmaputra sub-valleys (Fig. 3). The sloped surface extends $13 \mathrm{~km}$ basinward (south) from the outcropping Neogene to Quaternary uplands of the Garo Hills (BNGA110-123). This morphostratigraphic unit contains Holocene and Pleistocene Basinal Muds, which form a wedge-shape deposit that thickens toward the Dauki thrust fault. Angular clasts of Shillong Alluvium, sourced from local streams draining the Garo Hills, are interspersed within this mud wedge. The small rivers of the Garo Hills build local channel-levee deposits (100-500 $\mathrm{m}$ wide) across the foredeep and appear as thin (1-5 m) gravelly sand deposits within the much thicker Basinal Muds.

The foredeep mud wedge is underlain by Pleistocene Braidbelt Sands, indicating that the Brahmaputra river had occupied this location during the Pleistocene. Continued southward vergence of the Shillong Massif and increasing surface slope of the mud wedge may have been effective at precluding the Brahmaputra channel from reoccupying this area. Indeed, stratigraphy of the Dauki Foredeep ends abruptly at the eastern margin of the Old Brahmaputra Valley between BNGA109 and 110 . This transition is easily recognized by the distinct change in lithology from coarse, high-Sr, and high-MS Braidbelt Sands to the uniformly low-Sr, low-MS Basinal Muds and Shillong Alluvium (Fig. 7).

\section{Comparison of the Brahmaputra River Valleys}

In defining the LPSL (Latest Pleistocene Sea-level Lowstand) surface in the stratigraphy of the transect, we have identified discrete valleys that were formed by incisional river processes during sea-level lowering in the late Pleistocene. This surface reveals three paleo-river courses, including the modern Brahmaputra-Jamuna and two sub-valleys leading into the Sylhet basin, one along the Old Brahmaputra course and one adjacent to the north (Figs. 8, 9). Here we compare the geometry and morphostratigraphy of these valleys, which yield insights to the history of Brahmaputra channel migration and avulsion since the latest Pleistocene.

\subsection{Valley Floor Character and Lowstand River Course}

The two main valley systems of the Brahmaputra share similar stratigraphy, generally comprising $40-70 \mathrm{~m}$ of upward fining braidbelt sands capped by a surface veneer of floodplain muds. However, one distinguishing characteristic of the Brahmaputra-Jamuna valley is the thick basal gravel unit that floors the valley and represents a prominent lowstand lag surface (Fig. 8). This gravel bed defines the depth of refusal for most cores collected within the Jamuna valley, and the gravel bed's presence is corroborated through previous geotechnical drilling that penetrated the full thickness of the layer (Japan International Cooperation Agency, 1976; Goodbred and Kuehl, 2000). The drilling reveals the full gravel layer to comprise a 3-6 m layer of cobble- to boulder-sized clasts capped by $5-20 \mathrm{~m}$ of coarse sand and pebbles (Japan International Cooperation Agency, 1976); the depth of refusal for cores collected in the present study corresponds with upper coarse sand and pebble layer (Fig. 8). Compared with the sand-dominated aggradation that characterizes valley deposition during the Holocene, this late-glacial-period gravel bed likely reflects a comparative reduction in sandy bedload relative to water discharge, leading to formation of a coarse-grained lag surface. Alternatively, flow strength may have been high enough to transport these coarser grains as bedload material, with sand-sized particles bypassing this reach of the river as suspended load.

The broad $(\sim 40 \mathrm{~km})$, relatively flat floor of the valley also implies periods of sustained or repeated high water discharge relative to sediment discharge to develop such a planar, well-defined surface. These attributes are not necessarily consistent with the climate regime during the last glacial period, when discharge was considerably reduced under a weakened monsoon (Kudrass et al., 2001; Goodbred, 2003). One plausible solution to this apparent discrepancy may be the influence of episodic floods from failed ice-dammed lakes recorded along the Tsangporeach of the Brahmaputra (Montgomery et al., 2004; Lang et al., 2013). Such flood bursts would have been routed through the Bengal basin and possibly played a role in forming this gravel surface. At present, however, data from this study remain insufficient to confirm the origin of this prominent basal unit in the Brahmaputra-Jamuna valley system.

Regardless of the gravel bed's origin, such a surface is entirely absent from the Old Brahmaputra valleys. In fact the valley base along the Old Brahmaputra course is poorly defined and comprises largely continuous successions of medium-coarse sands, with only sparse pebble clasts. The Holocene-Pleistocene boundary within this section is only loosely constrained by a few radiocarbon ages, subtle downcore increases 
in oxidation state of the sands, and the presence of dried-mud clasts in some of the boreholes (Fig. 8). In general, though, the complete absence of a definable gravel unit or lowstand surface indicates that the Old Brahmaputra valley did not transmit the same large-magnitude discharge that was apparently routed through the broad, flat, gravelfloored Brahmaputra-Jamuna valley (Figs. 5, 8). The interpretation that no sustained, large discharge was transmitted through the Old Brahmaputra sub-valleys during the last lowstand is also consistent with shape of their valley floors, which are irregular and narrow $(<20 \mathrm{~km})$ with relatively high local relief (Fig. 9). These prominent differences in valleyfloor shape and lithology confirm that the Brahmaputra-Jamuna served as the principal river course during the last lowstand, a time during which there is little evidence for any sustained occupation of the Old Brahmaputra river course through Sylhet basin.

\subsection{Valley geometry and antecedant morphology}

\subsubsection{Brahmaputra-Jamuna Valley}

In addition to differences in the valley floors, the geometry of the Brahmaputra-Jamuna valley is distinct from that of the Old Brahmaputra sub-valleys in that it is considerably wider with an asymmetric morphology (Fig. 9). This asymmetry is reflected in the gentle slope of the western valley wall of the Brahmaputra-Jamuna Valley (slope = 0.002 ) compared with the steeper eastern wall (slope $=0.007$ ). The asymmetry may result in part through differences in lithology of the bounding units along each valley margin. Along the shallow sloping western margin, the Barind Tract's Pleistocene mud cap is friable, probably due to eluviation (i.e., mass loss) within the thick weathering profiles. By contrast the shallow stratigraphy of the Jamulpur terrace along the eastern valley margin comprises relatively younger Pleistocene muds that are less eluviated, more indurated, and overall less erodible. This difference facilitates bank erosion by the Brahmaputra River into the western wall of the valley, whereas the eastern valley wall at the Jamulpur terrace, several meters higher in elevation with a dense mudcap $>10 \mathrm{~m}$ thick, is less easily eroded.

Another feature of the Brahmaputra-Jamuna valley related to valley-wall asymmetry is the concentration of shallow $(<25 \mathrm{~m})$ Holocene-age gravels along the western margin (Fig. 5). The lithology of these gravels, reflected by the lower $\mathrm{Sr}$ and MS values along the western margin, is notably different from that of the central valley, which is dominated by higher 'end-member' values of the mainstem Brahmaputra (Fig. 7). This suggests that these gravels are sourced from the Tista River, whose alluvial fan intersects the Brahmaputra braidbelt just upstream of the coring transect. The incorporation of these Tistafan sediments, including sands and muds, into the Brahmaputra stratigraphy indicates the downstream transport of sediment reworked from the Tista fan through west lateral migration of the Brahmaputra, or possibly a lower point of confluence with the Tista in the past. The resulting stratigraphic unit lies near the surface and, at $\sim 10 \mathrm{~km}$ wide and $25-\mathrm{m}$ thick, is the size of the modern Brahmaputra braidbelt. These attributes suggest that the mixed Tista-Brahmaputra sediments reflect a single occupation of the Brahmaputra River along its extreme western margin during the mid-late Holocene. Thus, bounding of the Brahmaputra River along this margin may be more strongly influenced by the steep, coarse-grained Tista fan deposits than by the comparatively erodible Pleistocene mud cap of the Bogra terrace. These attributes differ from the steeper eastern valley margin where stiff muds of the Jamulpur Terrace, and not the underlying sandy lithology, are the dominant control on lateral channel migration.

Where the Brahmaputra River crosses the borehole transect, the modern braidbelt is $\sim 12 \mathrm{~km}$ wide with four cores collected directly within the braidbelt system (BNGA028-040; Figs. 3, 8). By comparison the Brahmaputra-Jamuna valley is $\sim 62 \mathrm{~km}$ wide at ground surface, or more than five times the mean braidbelt width of the river. This valley:channel width ratio $(>5)$ characterizes the Brahmaputra River as an unconfined fluvial system having a high degree of potential mobility
(Gibling, 2006). Indeed the overwhelmingly sandy stratigraphy, with little to no preservation of Overbank Muds, reflects either persistent lateral migration of the Brahmaputra braidbelt from one valley margin to the other, or multiple discrete occupations through the Holocene that successively eroded away previously deposited muds. (Fig. 8). Another product of the Brahmaputra-Jamuna's lateral mobility is the mixed Tista-Brahmaputra braidbelt unit along the western valley margin, which represents an extension of the valley beyond its lowstand margins through lateral erosion. With a mean valley depth of $58 \mathrm{~m}$, a width-to-thickness (W/T) ratio of $\sim 1000$ for the Brahmaputra-Jamuna valley reflects lateral mobility of the river braidbelt as well and is composed of stacked multistory channel bodies that fine upwards. Thus the Brahmaputra has maintained a braided or low-sinuosity river planform within a mobile-channel belt throughout the Holocene, which is consistent with the sand and minor gravels dominating the overall finingupward stratigraphy. Together these attributes confirm that the river is free to accrete laterally through bank migration within the Brahmaputra-Jamuna valley, which overall should increase the time that the river can occupy this valley before avulsing to the Old Brahmaputra course.

\subsubsection{Old Brahmaputra valley system}

Subtle topography of the eighteenth century Brahmaputra braidbelt and levee system can be observed flanking the Old Brahmaputra river channel, which was cored at four sites from BNGA083 to 091 (Figs. 3, 8). The eastern bank of the abandoned braidbelt lies at the town of Sherpur (see "Seer pour" on the Rennel map), which is mapped on the channel margin in Major Rennel's historical 1776 map (Rennell and Dury, 1776; Best et al., 2007). Core BNGA094 was collected within Sherpur and reveals that the town lies upon stiff, oxidized Pleistocene muds that lie at a relatively higher elevation than adjacent boreholes within the Old Brahmaputra valley (Fig. 3). From these findings it is clear that the town of Sherpur was established upon a remnant of the Pleistocene Jamulpur Terrace that was not eroded during valley incision.

This antecedent feature also bifurcates the Old Brahmaputra valley into two distinct sub-valleys, one associated with the Old Brahmaputra river course (sub-valley A) and another to the northeast (sub-valley B) that is $\sim 12 \mathrm{~km}$ wide and extends from drilling sites BNGA097 to 109 (Figs. 3, 8). Unlike the Brahmaputra-Jamuna valley, the Old Brahmaputra sub-valleys are narrow and laterally constrained by shallow to exposed Pleistocene deposits. Both valleys are just the width of a single braidbelt ( $12 \mathrm{~km}$; Fig. 9), and lateral migration and erosion of the valley margins are less apparent here than in the Brahmaputra-Jamuna valley. For example, the valley walls are considerably steeper than those of the Brahmaputra-Jamuna valley (slope: 0.005 to 0.007 ), with sub-valley A having mean valley-wall slopes of 0.007 and 0.013 and sub-valley B with slopes of 0.016 and 0.022 for their western and eastern margins, respectively. The relatively steep valley walls indicate that former Brahmaputra channel systems within the Old Brahmaputra valleys have not migrated laterally but have preferentially incised and aggraded in the vertical direction throughout the Holocene.

Such behavior is further reflected in the relatively low width-tothickness (W/T) ratios in each valley, with values of $\sim 250$ and $\sim 125$ for sub-valleys A and B, respectively. Such results are typical of fixed delta distributary channels and indicate that incision of these valleys was primarily the result of vertical scour and not lateral migration (Gibling, 2006). Despite these major differences with the much broader Brahmaputra-Jamuna valley, the valley-fill stratigraphy, dominated by sand with a minor gravel component, an overall fining-upward sequence, and rare mud preservation, is remarkably similar. The emerging conclusion is that the large, bedload-rich, braided Brahmaputra River constructs a sand-dominated stratigraphy in these upper-delta, riverdominated reaches of the Bengal basin. In terms of fluvial behavior, these attributes indicate that the Old Brahmaputra channel was forced to aggrade vertically due to impeded bank migration resulting from the cohesive Jamulpur Terrace sediments that comprise the boundaries 
of these sub-valleys. Furthermore these constraints have led to successive reoccupation of the former river channels because the valleys are only the width of single braidbelt system. One consequence is that this vertical aggradation within narrow reoccupied channels favors shorter occupation times and forced avulsion back to the broader Brahmaputra-Jamuna valley where the braidbelt is laterally mobile.

\subsection{Holocene avulsion history}

Results from this and previous studies reveal that widespread sediment deposition and delta formation began after 11 ka while sea-level was still rising rapidly, during which time the Brahmaputra River occupied its western course through the Brahmaputra-Jamuna valley until 7500 cal BP (Goodbred and Kuehl, 2000). Radiocarbon dates from this study demonstrate that Braidbelt Sands were deposited in the Brahmaputra-Jamuna valley at $\sim 7800$ and $\sim 8800$ cal BP (Table 2). Additionally, Overbank Muds dating to $\sim 6500$ cal BP are preserved (uncommonly) in the Brahmaputra-Jamuna valley at $\sim 60 \mathrm{~m}$ below the modern surface, likely representing an avulsion into the Old Brahmaputra valley system. This occupation of the Brahmaputra River in Sylhet basin roughly between 7500 and 5500 cal BP is consistent with previous cores from the region (Goodbred and Kuehl, 2000). Within sub-valley A specifically, Braidbelt Sands were deposited at $\sim 9500$ and $\sim 500$ cal BP (Fig. 8). Interestingly, the $\sim 9500$ cal BP date underlies a unit of mildly oxidized sands (see Section 5.4), suggesting that there was an extended period of exposure ( 2000 years) following this apparently brief, early Holocene occupation of the Old Brahmaputra sub-valley A. Perhaps the brevity of this occupation coupled with the relative thinness of this braidbelt deposit suggests that the occupation at 9500 cal BP was a partial avulsion into the Old Brahmaputra valley and that substantial flow did not return to sub-valley A until the most recent occupation prior to the eighteenth century, which likely correlates with the $\sim 500$ cal BP date. There is no evidence to suggest that the river occupied the sub-valley A path between the $\sim 9500$ cal BP occupation and the most recent occupation, although there is evidence for a major midHolocene occupation of the Sylhet basin (Goodbred and Kuehl, 2000; Goodbred et al., in press), probably through sub-valley B.

The two radiocarbon dates from sub-valley $B$ are mid-Holocene in age, $\sim 6700$ and $\sim 6800$ cal BP and suggest that the Brahmaputra River was routed through sub-valley B as a major occupation of the Sylhet basin (e.g., Goodbred and Kuehl, 2000; Goodbred et al., in press). Together these results from the Old Brahmaputra valley system suggest three Holocene occupations of the Brahmaputra River in the Sylhet basin: a brief, early Holocene connection 9500 cal BP through sub-valley A, followed several thousand years later by a major longer-term occupation through sub-valley B, and finally the most recent late Holocene occupation through sub-valley A. Comparatively, the main river was located in the Brahmaputra-Jamuna valley during lowstand and through much of the early Holocene and much of the late Holocene. When coupled with the alternating occupations of Sylhet basin, this requires six avulsions or partial avulsions since the start of delta formation $\sim 11,000 \mathrm{cal} \mathrm{BP}$, yielding a mean occupation period of $\sim 1800$ years and avulsion frequency of $5.5 \times 10^{-4} \mathrm{yr}^{-1}$. These first-order estimates of channel occupation timescales provide useful data for testing theories about river avulsion behavior.

For comparison with these mean occupation timescales, we consider the time required for the Brahmaputra sediment load to infill the Sylhet basin and thus favor avulsion of the river from its Old Brahmaputra course back to the Brahmaputra-Jamuna valley. With a modern sediment load of $\sim 600 \mathrm{Mt} / \mathrm{yr}$ and typical bulk density of $1.5 \mathrm{t} / \mathrm{m}^{3}$ for deposited sediments, $\sim 400 \times 10^{6} \mathrm{~m}^{3}$ of sediment are transported into the $\sim 10,000 \mathrm{~km}^{2}$ Sylhet basin each year. Assuming efficient trapping within the subsiding (3-4 mm/yr), low-lying basin, these values yield a mean accretion rate of up to $\sim 4 \mathrm{~cm} / \mathrm{yr}$ across the region. Such rates could account for $4 \mathrm{~m}$ of aggradation in just one century, indicating that the subsiding Sylhet basin would be rapidly infilled by Brahmaputra discharge while occupying the Old Brahmaputra valley system. Even at only $\sim 30 \%$ trapping efficiency, the mean estimate for this delta (Goodbred and Kuehl, 1998, 1999), a full meter of aggradation could occur in 100 years.

The implication emerging from this simple budget calculation is that the occupation time of the Brahmaputra river within Sylhet basin is not likely to persist for more than a few centuries on average, unless the river is able to bypass sediment through the Meghna channel to the coast. Additionally, recent preliminary results of DEM analyses reveal that the Sylhet basin river course is longer and less steep than the more direct route along the Brahmaputra-Jamuna valley. Overall, these characteristics do not favor long-term occupation of the Old Brahmaputra course despite subsidence within the Sylhet basin. While subsidence may be an important control in triggering an avulsion into the basin, the occupation time is probably less, on average, than that for the broad, straight Brahmaputra-Jamuna valley.

This observation that the relict valleys are still influencing channel path selection behavior 11,000 years later is significant to the theory of channel reoccupation behavior, i.e. how strongly channel path selection can be influenced by reoccupation (Leeder, 1978; Aslan et al., 2005; Reitz et al., 2010). The Brahmaputra has been switching between 2-3 primary channel paths for the past 6 avulsion events, probably due to the presence of antecedent incised topography and the bounding Pleistocene muds. As a topic for future inquiry, these effects may present a similar influence on reoccupying path selection for other large deltas that incised following the drop in sea-level (Blum and Tornqvist, 2000; Törnqvist et al., 2000).

\section{Summary}

The Brahmaputra River has cut and filled a system of valleys downstream of a principal avulsion node in the upper delta plain of the Bengal basin. The Brahmaputra-Jamuna and Old Brahmaputra valleys are flanked by macroform topographic bounding surfaces that have persisted since the late Pleistocene. These Pleistocene-aged terraces consist of oxidized sands and stiff muds that flank the BrahmaputraJamuna valley and the west side of the Old Brahmaputra valley, and the Dauki Foredeep basin flanks the east side of the Old Brahmaputra valley. Each of these paleovalleys is filled with Holocene-aged fluvial sediments that reveal four distinct facies deposited in this upper delta plain. These consist primarily of sands that represent fluvial braidbelt deposits and finer-grained sediments that represent overbank and basin deposits. Although Overbank Muds are commonly preserved at the surface of boreholes, very few are preserved in the deeper stratigraphy, suggesting that these deposits are eroded and reworked as the rivers migrate laterally or incise and aggrade. From the distribution of sediments along Transect $\mathrm{A}$, together with the surface morphology, historical accounts, and recent research, we have documented at least 6 significant avulsions or partial avulsions of the Brahmaputra River since $\sim 11,000 \mathrm{cal}$ BP. In the Brahmaputra-Jamuna valley, the dominant river behavior responsible for building and reworking the stratigraphy is lateral migration and accretion, increasing the mean occupation time of this course. In the Old Brahmaputra valley, however, the dominant river behavior is relatively rapid channel aggradation with little lateral motion that results in generally shorter occupation times before avulsing back to the main course.

\section{Acknowledgments}

We gratefully acknowledge H. Briel, Z. Mahmood, C. Tasich, M. Cooley, and W. Cribb for assistance with fieldwork and analyses. We acknowledge the NOSAMS Facility and associated support by the NSF Cooperative Agreement number, OCE-0753487. Thanks to C. Wilson and to the anonymous reviewers whose suggestions greatly enhanced this paper. Many thanks are also due to M. Sinha for his help with the Bengali language and the typesetting of this manuscript. We further 
Table 2

Radiocarbon ages recovered from organic material in Transect A sediments.

\begin{tabular}{|c|c|c|c|c|c|c|c|c|c|c|}
\hline Lab ID & Sample ID & Site & Depth (m) & Material & $\delta^{13} \mathrm{C}$ & ${ }^{14} \mathrm{C}$ age $\mathrm{BP}$ & Error & cal yr BP & $2 \sigma$ upper & $2 \sigma$ lower \\
\hline OS-92971 & BNGA00812-24 & 008 & 23.5 & Plant/wood & -21.78 & > Modern & & Modern & & \\
\hline OS-94369 & BNGA02314 & 031 & 14 & Plant/wood & -30.93 & > Modern & & Modern & & \\
\hline OS-94329 & BNGA02346 & 023 & 46 & Plant/wood & -31.91 & > Modern & & Modern & & \\
\hline OS-94329 & BNGA02829 & 028 & 29 & Plant/wood & -31.55 & > Modern & & Modern & & \\
\hline OS-94317 & BNGA02840 & 028 & 40 & Plant/wood & -26.52 & 7020 & \pm 35 & 7863 & 7785 & 7940 \\
\hline OS-94318 & BNGA03615 & 036 & 15 & Plant/wood & -19.43 & 390 & \pm 25 & 468 & 428 & 508 \\
\hline OS-94328 & BNGA03638 & 036 & 38 & Plant/wood & -28.24 & 7980 & \pm 45 & 8848 & 8696 & 8999 \\
\hline OS-92939 & BNGA05559 & 055 & 59 & Plant/wood & -29.62 & 5800 & \pm 30 & 6586 & 6502 & 6669 \\
\hline OS-92940 & BNGA08134 & 081 & 34 & Plant/wood & -26.36 & $>48,000$ & & $>48,000$ & & \\
\hline OS-94327 & BNGA08521 & 085 & 21 & Plant/wood & -28.99 & 8580 & \pm 45 & 9558 & 9484 & 9631 \\
\hline OS-94319 & BNGA09127 & 091 & 27 & Plant/wood & -14.01 & $405 \hat{A}$ & \pm 25 & 474 & 435 & 513 \\
\hline OS-92981 & BNGA09735 & 097 & 35 & Plant/wood & -23.84 & 5980 & \pm 45 & 6829 & 6717 & 6940 \\
\hline OS-92941 & BNGA09739 & 097 & 39 & Plant/wood & -13.58 & 5930 & \pm 35 & 6736 & 6667 & 6804 \\
\hline OS-92942 & BNGA10912 & 109 & 12 & Plant/wood & -27.33 & 695 & \pm 25 & 665 & 645 & 683 \\
\hline OS-92943 & BNGA11008 & 110 & 08 & Plant/wood & -28.64 & 4130 & \pm 30 & 4648 & 4566 & 4729 \\
\hline OS-92983 & BNGA11018 & 110 & 18 & Sediment (TOC) & -12.13 & 41,300 & \pm 480 & $>48,000$ & & \\
\hline OS-92995 & BNGA11211 & 112 & 11 & Plant/wood & -30.22 & 5510 & \pm 35 & 6337 & 6275 & 6398 \\
\hline OS-92944 & BNGA11456 & 114 & 56 & Plant/wood & -14.19 & $>48,000$ & & $>48,000$ & & \\
\hline OS-92970 & BNGA11463 & 114 & 63 & Plant/wood & -31.8 & > Modern & & Modern & & \\
\hline OS-92987 & BNGA12129 & 121 & 29 & Plant/wood & -13.87 & $>48,000$ & & $>48,000$ & & \\
\hline OS-92985 & BNGA12356 & 123 & 56 & Sediment (TOC) & -11.78 & 43,200 & \pm 730 & $>48,000$ & & \\
\hline
\end{tabular}

acknowledge our "BanglaPIRE" collaborators: L. Seeber, M. Steckler, E. Ferguson, C. Paola, A. Petter, H. Akhter, V. Speiß, T. Schwenk, and C. McHugh. Funding for this research was provided by NSF PIRE Award \#0968354.

\section{References}

Alam, M., Shahidul Hasan, A.K.M., Khan, M., Whitney, J., 1990. Geological map of Bangladesh. Map. Geological Survey of Bangladesh. (Dhaka).

Aslan, A., Autin, W.J., Blum, M.D., 2005. Causes of river avulsion: insights from the Late Holocene avulsion history of the Mississippi River, U.S.A. J. Sediment. Res. 75, 650-664

Baki, A.B.M., Gan, T.Y., 2012. Riverbank migration and island dynamics of the braided Jamuna River of the Ganges-Brahmaputra basin using multi-temporal Landsat images. Quat. Int. 263, 148-161.

Best, J.L., Ashworth, P.J., Sarker, M.H., Roden, J.E., 2007. The Brahmaputra-Jamuna River, Bangladesh. In: Gupta, A. (Ed.), Large Rivers. John Wiley \& Sons, Ltd. pp. 395-433.

Blum, M.D., Tornqvist, T.E., 2000. Fluvial responses to climate and sea-level change: a review and look forward. Sedimentology 47, 2-48.

Brammer, H., Brinkman, R., 1977. Surface-water gley soils in Bangladesh: environment landforms and soil morphology. Geoderma 17, 91-109.

Bristow, C., 1999. Gradual avulsion, river metamorphosis and reworking by underfit streams: a modern example from the Brahmaputra River in Bangladesh and a possible ancient example in the Spanish Pyranees. In: Blum, M., Marriott, S.B., Leclair, S.F. (Eds.), Fluvial Sedimentology 7. International Association of Sedimentologists, pp. 221-230.

Bryant, M., Falk, P., Paola, C., 1995. Experimental study of avulsion frequency and rate of deposition. Geology 23, 365-368.

Cazanacli, D., Paola, C., Parker, G., 2002. Experimental steep, braided flow: application to flooding risk on fans. J. Hydraul. Eng. 128, 322-330.

Chakraborty, T., Ghosh, P., 2010. The geomorphology and sedimentology of the Tista megafan, Darjeeling Himalaya: implications for megafan building processes. Geomorphology 115, 252-266.

Coleman, J., 1969. Brahmaputra River: channel processes and sedimentation. Sediment. Geol. 3, 129-239.

DeCelles, P.G., Cavazza, W., 1999. A comparison of fluvial megafans in the Cordilleran (Upper Cretaceous) and modern Himalayan foreland basin systems. Geol. Soc. Am Bull. 111, 1315-1334

Delft Hydraulics and Danish Hydraulic Institute, 1996. (FAP 24) special report no. 18 sediment rating curves and balances. Tech. rep.Danish Hydraulic Institute.

EGIS, 1997. Morphological Dynamics of the Brahmaputra-Jamuna River. Tech. rep.Environmental and GIS Support Project for Water Sector Planning, Dhaka.

Fergusson, J., 1863. Delta of the Ganges. Q. J. Geol. Soc. Lond. 29, 321-354.

Garzanti, E., Vezzoli, G., Ando, S., France-lanord, C., Singh, S.K., Foster, G., 2004. Sand petrology and focused erosion in collision orogens: the Brahmaputra case. Earth Planet. Sci. Lett. 220, 157-174.

Gibling, M.R., 2006. Width and thickness of fluvial channel bodies and valley fills in the geological record: a literature compilation and classification. J. Sediment. Res. 76, 731-770.

Goodbred, S.L., 2003. Response of the Ganges dispersal system to climate change; a source-to-sink view since the last interstade. Sediment. Geol. 162, 83-104.

Goodbred, S.L., Kuehl, S.A., 1998. Floodplain processes in the Bengal Basin and the storage of Ganges-Brahmaputra river sediment: an accretion study using ${ }^{137} \mathrm{Cs}$ and ${ }^{210} \mathrm{~Pb}$ geochronology. Sediment. Geol. 121, 239-258.
Goodbred, S.L., Kuehl, S.A., 1999. Holocene and modern sediment budgets for the GangesBrahmaputra river system: evidence for highstand dispersal to flood-plain, shelf, and deep-sea depocenters. Geology 27, 559-562.

Goodbred, S.L., Kuehl, S.A., 2000. The significance of large sediment supply, active tectonism, and eustasy on margin sequence development: Late Quaternary stratigraphy and evolution of the Ganges-Brahmaputra delta. Sediment. Geol. 133, 227-248.

Goodbred, S.L., Kuehl, S.A., Steckler, M.S., Sarker, M.H., 2003. Controls on facies distribution and stratigraphic preservation in the Ganges-Brahmaputra delta sequence. Sediment. Geol. 155, 301-316.

Goodbred, S.L., Youngs, P.M., Ullah, M.S., Pate, R.D., Khan, S.R., Kuehl, S.A., Singh, S.K., Rahaman, W., 2013. Piecing together Holocene stratigraphy of the GangesBrahmaputra-Meghna river delta using Sr sediment geochemistry: implications for river behavior and delta evolution. Geol. Soc. Am. Bull. (in press).

Hoque, M.A., McArthur, J.M., Sikdar, P.K., 2012. The palaeosol model of arsenic pollution of groundwater tested along a $32 \mathrm{~km}$ traverse across West Bengal, India. Sci. Total Environ. 431, 157-165.

Hoyal, D.C.J.D., Sheets, B.A., 2009. Morphodynamic evolution of experimental cohesive deltas. J. Geophys. Res. 114, 1-18.

Jain, V., Sinha, R., 2003. Hyperavulsive-anabranching Baghmati river system, north Bihar plains, eastern India. Z. Geomorphol. 47, 101-116.

Japan International Cooperation Agency, 1976. Geology and stone material: Jamuna Bridge construction project. Tech. rep.Japan International Cooperation Agency, Tokyo.

Kim, W., Sheets, B.a., Paola, C., 2010. Steering of experimental channels by lateral basin tilting. Basin Res. 22, 286-301

Kudrass, H.R., Hofmann, A., Doose, H., Emeis, K., Erlenkeuser, H., 2001. Modulation and amplification of climatic changes in the Northern Hemisphere by the Indian summer monsoon during the past 80 k.y. Geology 29, 63-66.

Lang, K.A., Huntington, K.W., Montgomery, D.R., 2013. Erosion of the Tsangpo Gorge by megafloods, Eastern Himalaya. Geology 41, 1003-1006.

Leeder, M., 1978. A quantitative stratigraphic model for alluvium, with special reference to channel deposit density and interconnectedness. In: Miall, A.D. (Ed.), Fluvial Sedimentology, 5, pp. 587-596.

Maher, B.A., Watkins, S.J., Brunskill, G., Alexander, J., Fielding, C.R., 2009. Sediment provenance in a tropical fluvial and marine context by magnetic "fingerprinting" of transportable sand fractions. Sedimentology 56, 841-861.

McArthur, J.M., Ravenscroft, P., Banerjee, D.M., Milsom, J., Hudson-Edwards, K.A., Sengupta, S., Bristow, C., Sarkar, A., Tonkin, S., Purohit, R., 2008. How paleosols influence groundwater flow and arsenic pollution: a model from the Bengal Basin and its worldwide implication. Water Resour. Res. 44 (11), 1-30.

Métivier, F., Gaudemer, Y., Tapponnier, P., Klein, M., 1999. Mass accumulation rates in Asia during the Cenozoic. Geophys. J. Int. 137, 280-318.

Mohrig, D., Heller, P.L., Paola, C., Lyons, W.J., 2000. Interpreting avulsion process from ancient alluvial sequences: Guadalope-Matarranya system (northern Spain) and Wasatch Formation (western Colorado). Geol. Soc. Am. Bull. 112, 1787-1803.

Montgomery, D.R., Hallet, B., Yuping, L., Finnegan, N., Anders, A., Gillespie, A., Greenberg, H.M., 2004. Evidence for Holocene megafloods down the Tsangpo River gorge, southeastern Tibet. Quat. Res. 62, 201-207.

Morgan, J.P., McIntire, W.G., 1959. Quaternary Geology of the Bengal Basin, East Pakistan and India. Bull. Geol. Soc. Am. 70, 319-342.

Oldham, R.D., 1899. Report of the great earthquake of12th June, 1897. Mem. Geol. Surv. India 29, 377.

Rashid, T., Monsur, M.H., Suzuki, S., 2006. A review on the Quaternary characteristics of Pleistocene tracts of Bangladesh. Okayama University Earth Science Reports, 13 1-13.

Reitz, M.D., Jerolmack, D.J., Swenson, J.B., 2010. Flooding and flow path selection on alluvial fans and deltas. Geophys. Res. Lett. 37 (6), 1-5. 
Rennell, J., Dury, A., 1776. An Actual Survey, of the Provinces of Bengal, Bahar. Map, Laurie \& Whittle, London.

Sarkar, A., Sengupta, S., Mcarthur, J.M., Ravenscroft, P., Bera, M.K., Bhushan, R., Samanta, A., Agrawal, S., 2009. Evolution of Ganges-Brahmaputra western delta plain: clues from sedimentology and carbon isotopes. Quat. Sci. Rev. 28, 2564-2581.

Sarker, M.H., Huque, I., Alam, M., Koudstaal, R., 2003. Rivers, chars and char dwellers of Bangladesh. Int. J. River Basin Manage. 1, 61-80.

Schumm, S., Mosley, M., Weaver, W., 1987. Experimental Fluvial Geomorphology. Wiley, New York (413 pp.).

Singh, S.K., France-lanord, C., 2002. Tracing the distribution of erosion in the Brahmaputra watershed from isotopic compositions of stream sediments. Earth Planet. Sci. Lett. 202, 645-662.

Slingerland, R., Smith, N.D., 2004. River avulsions and their deposits. Annu. Rev. Earth Planet. Sci. 32, 257-285.

Stuiver, M., Reimer, P., 1993. Extended ${ }^{14} \mathrm{C}$ data base and revised CALIB $3.0{ }^{14} \mathrm{C}$ age calibration program. Radiocarbon 35, 215-230.
Thorne, C.R., Russell, A.P.G., Alam, M.K., 1993. Planform pattern and channel evolution of the Brahmaputra River, Bangladesh. In: Sambrook Smith, G.H., Best J.L., Bristow, C., Petts, G.E., Jarvis, I. (Eds.), Braided Rivers. Wiley-Blackwell, pp. 257-276.

Törnqvist, T., Wallinga, J., Murray, A.S., de Wolf, H., Cleveringa, P., de Gans, W., 2000. Response of the Rhine-Meuse system (west-central Netherlands) to the last Quaternary glacio-eustatic cycles: a first assessment. Glob. Planet. Chang. 27, 89-111.

Umitsu, M., 1987. Late Quaternary sedimentary environment and landform evolution in the Bengal lowland. Geogr. Rev. Jpn 60, 164-178.

Umitsu, M., 1993. Late Quaternary sedimentary environments and landforms in the Ganges Delta. Sediment. Geol. 83, 177-186.

Whipple, K., Parker, G., Paola, C., Mohrig, D., 1998. Channel dynamics, sediment transport and the slope of alluvial fans: experimental study. J. Geol. 106, 677-694.

Zhang, W., Xing, Y., Yu, L., Feng, H., Lu, M., 2008. Distinguishing sediments from the Yangtze and Yellow Rivers, China: a mineral magnetic approach. The Holocene 18, 1139-1145. 